Pacific Northwest

National Laboratory

Operated by Battelle for the

U.S. Department of Energy

\section{Fiscal Year 2005 \\ Integrated Monitoring Plan for the Hanford Groundwater Performance Assessment Project}

J. T. Rieger

M. J. Hartman

June 2005

Prepared for the U.S. Department of Energy under Contract DE-AC05-76RL01830 


\title{
DISCLAIMER
}

This report was prepared as an account of work sponsored by an agency of the United States Government. Reference herein to any specific commercial product, process, or service by trade name, trademark, manufacturer, or otherwise does not necessarily constitute or imply its endorsement, recommendation, or favoring by the United States Government or any agency thereof, or Battelle Memorial Institute.

\author{
PACIFIC NORTHWEST NATIONAL LABORATORY \\ operated by \\ BATTELLE \\ for the \\ UNITED STATES DEPARTMENT OF ENERGY \\ under Contract DE-AC05-76RL01830
}

\author{
Printed in the United States of America \\ Available to DOE and DOE contractors from the \\ Office of Scientific and Technical Information, P.O. Box 62, Oak Ridge, TN 37831; \\ prices available from (615) 576-8401. \\ Available to the public from the National Technical Information Service, \\ U.S. Department of Commerce, 5285 Port Royal Rd., Springfield, VA 22161
}




\title{
Fiscal Year 2005 Integrated Monitoring Plan for the Hanford Groundwater Performance Assessment Project
}

\author{
J. T. Rieger \\ M. J. Hartman
}

June 2005

Prepared for

the U.S. Department of Energy

under Contract DE-AC05-76RL01830

Pacific Northwest National Laboratory

Richland, Washington 99352 



\section{Summary}

Groundwater is monitored in hundreds of wells at the Hanford Site to fulfill a variety of requirements. Separate monitoring plans are prepared for various purposes, but sampling is coordinated and data are shared among users. The U.S. Department of Energy (DOE) manages these activities through the Hanford Groundwater Performance Assessment Project (groundwater project), which is the responsibility of Pacific Northwest National Laboratory. The groundwater project integrates monitoring for various objectives into a single sampling schedule to avoid redundancy of effort and to improve efficiency of sample collection.

The report documents the purposes and objectives of groundwater monitoring, which fall into three general categories: (1) plume and trend tracking, (2) monitoring of treatment/storage/disposal units, and (3) independent assessment of performance monitoring for groundwater remediation activities.

The table of wells and constituents in Appendix A was constructed by querying the groundwater project's schedule database. This table was constructed mid-way through fiscal year 2005 and includes changes that were made to the baseline schedule, such as added sampling events (e.g., to confirm questionable results or critical mean exceedance) or cancelled sampling events (e.g., removing dry wells or reflecting plan revisions). A version of this schedule is available on the groundwater project's website (http://groundwater.pnl.gov) and is updated periodically to reflect schedule changes. 



\section{Contents}

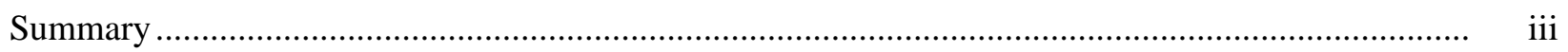

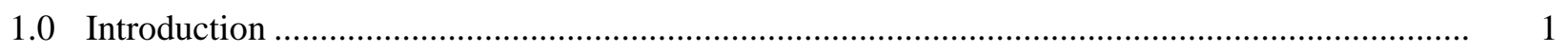

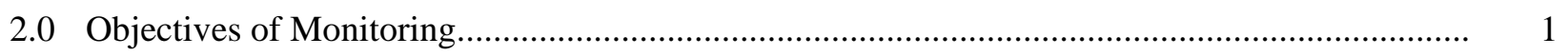

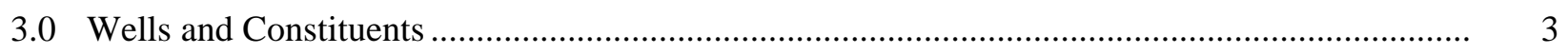

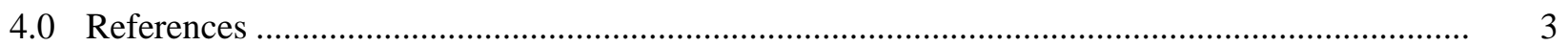

Appendix - Table of Wells and Constituents

\section{Figures}

1 Hanford Site Groundwater Interest Areas ......................................................................... 5

2 Groundwater Monitoring Wells in the 600 Area ................................................................... 7

3 Groundwater Monitoring Wells in the 100-B/C Area ............................................................ 9

4 Groundwater Monitoring Wells in the 100-K Area.............................................................. 10

5 Groundwater Monitoring Wells in the 100-N Area................................................................... 11

$6 \quad$ Groundwater Monitoring Wells in the 100-D Area................................................................... 12

$7 \quad$ Groundwater Monitoring Wells Near the Redox Site in the 100-D Area.................................... 13

8 Groundwater Monitoring Wells in the 100-H Area.................................................................... 14

9 Groundwater Monitoring Wells in the 100-F Area ................................................................ 15

10 Groundwater Monitoring Wells in the 200 West Area........................................................... 17

11 Groundwater Monitoring Wells in the 200 East Area ............................................................... 19

12 Groundwater Monitoring Wells in the 600 Area Associated With the 200-BP-5 Operable

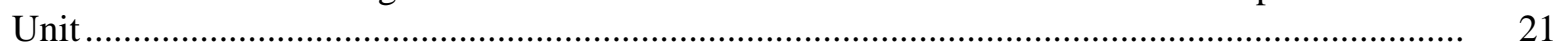

13 Groundwater Monitoring Wells at the Central Landfill ........................................................ 22

14 Groundwater Monitoring Wells in the 400 Area ................................................................... 23

15 Groundwater Monitoring Wells at the 618-10 and 618-11 Burial Grounds ............................... 24

16 Groundwater Monitoring Wells in the 300 Area and 1100-EM-1 Interest Area......................... 25

\section{Table}

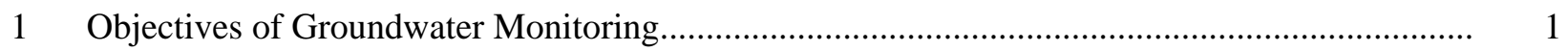





\subsection{Introduction}

Groundwater is monitored in hundreds of wells at the Hanford Site to fulfill a variety of requirements. Separate monitoring plans are prepared for various requirements, but sampling is coordinated and data are shared among users. The U.S. Department of Energy (DOE) manages these activities through the Hanford Groundwater Performance Assessment Project (groundwater project), which is the responsibility of Pacific Northwest National Laboratory. The groundwater project integrates monitoring for various objectives into a single sampling schedule to avoid redundancy of effort and to improve efficiency of sample collection.

\subsection{Objectives of Monitoring}

The Environmental Monitoring Plan (DOE 2002) lists the purposes and objectives of groundwater monitoring and the groundwater project. These purposes and objectives fall into three general categories: (1) plume and trend tracking, (2) monitoring of treatment/storage/disposal units, and (3) independent assessment of performance monitoring for groundwater remediation activities (Table 1).

Table 1. Objectives of Groundwater Monitoring

\begin{tabular}{|c|}
\hline $\begin{array}{l}\text { Plume and Trend Tracking } \\
\text { - } \quad \text { Determine baseline conditions of groundwater quality and quantity. } \\
\text { - } \text { Characterize and define hydrogeologic, physical, and chemical trends in the groundwater system. } \\
\text { - Identify existing and potential groundwater contamination sources. } \\
\text { - Assess existing and emerging groundwater problems. } \\
\text { - Evaluate existing and potential offsite impact of groundwater contaminants. } \\
\text { - Provide data on which decisions can be made concerning land-disposal practices and management } \\
\text { and protection of groundwater resources. }\end{array}$ \\
\hline $\begin{array}{l}\text { Treatment/Storage/Disposal Unit Monitoring } \\
\text { - Demonstrate compliance with applicable regulations and orders (RCRA, WAC). } \\
\text { - Provide data to permit early detection of groundwater pollution or contamination. }\end{array}$ \\
\hline $\begin{array}{l}\text { Groundwater Remediation Performance Monitoring } \\
\text { - Provide continuing, independent assessment of groundwater remediation activities. }\end{array}$ \\
\hline
\end{tabular}

Plume and trend tracking are the primary objectives of long-term monitoring under the Comprehensive Environmental Response, Compensation, and Liability Act (CERCLA) and the Atomic Energy 
Act of 1954 (AEA). Treatment/storage/disposal unit monitoring includes units regulated under the Resource Conservation and Recovery Act (RCRA) or Washington Administrative Code (WAC) (recently active sites), CERCLA (past-practice sites), and the AEA. Monitoring associated with groundwater remediation activities is performed by Fluor Hanford, Inc. The groundwater project is responsible for “providing continuing, independent assessment of groundwater remediation activities” (DOE 2002).

For groundwater characterization and cleanup, groundwater beneath waste sites is grouped into operable units. The formal groundwater operable units do not include the entire Hanford Site. Therefore, to provide scheduling, data review, and interpretation for the entire Hanford Site, the groundwater project has informally defined "groundwater interest areas" that generally correspond to the groundwater operable units. Figure 1 illustrates these interest areas and the operable unit boundaries. Figures 2 through 16 are well location maps.

The groundwater project is responsible for groundwater monitoring for the following purposes:

- RCRA treatment/storage/disposal unit monitoring

- Performance assessment monitoring at low-level burial grounds under the AEA

- CERCLA monitoring at operable units without active groundwater remediation

- Monitoring of the Solid Waste Landfill under WAC 173-216

- Monitoring to supplement monitoring conducted under other programs for AEA objectives (e.g., monitoring of 100-K fuel storage basins, monitoring radionuclides at RCRA sites)

- Special sampling to support research projects or other special needs (not included in this monitoring plan)

In addition, DOE has instructed the groundwater project to integrate groundwater sample collection in the following cases:

- CERCLA monitoring at operable units with active groundwater remediation

- Monitoring of the Environmental Restoration Disposal Facility under CERCLA

- Monitoring by the Washington State Department of Health for independent assessment of Site conditions

Groundwater sampling is performed for a few purposes outside of the groundwater project. Those samples are scheduled independently by the responsible contractor. Where possible, sampling trips are coordinated between projects to avoid redundancy. Groundwater monitoring activities that are performed independently and are not captured in this integrated monitoring plan include:

- In-process monitoring of groundwater remediation systems for the evaluation of system performance

- Characterization monitoring performed during installation of new wells 
- Groundwater monitoring of the State-Approved Land Disposal Site and the Treated Effluent Disposal Facility under WAC 173-216

- Near-facility monitoring near the Columbia River at the 100-N Springs

- In-system monitoring of the 400 Area drinking water supply

\subsection{Wells and Constituents}

The table of wells and constituents in Appendix A of this integrated monitoring plan was constructed by querying the groundwater project's schedule database. The table shows the number of times that a well is scheduled to be sampled in fiscal year 2005 for each constituent (or constituent group such as anions). Many wells are listed multiple times in this table because they are co-sampled for the objectives of more than one project or waste management area. Sampling is coordinated to avoid duplication. The table does not include quality control (QC) samples, samples collected during drilling of new wells, or shoreline seeps. Wells scheduled biennially or triennially are only listed in the table if they are scheduled for fiscal year 2005. The table does not include sampling conducted outside the groundwater project, such as operational sampling associated with pump-and-treat systems, monitoring of the 200 Area Treated Effluent Disposal Facility, or State-Approved Land Disposal Site.

This table was constructed mid-way through fiscal year 2005 and includes changes that were made to the baseline schedule, such as added sampling events (e.g., to confirm questionable results or critical

mean exceedance) or cancelled sampling events (e.g., removing dry wells or reflecting plan revisions). A version of this schedule is available on the groundwater project's website (http://groundwater.pnl.gov) and is updated periodically to reflect schedule changes.

In addition to the constituents listed in the table in this plan, samples are analyzed in the field for temperature, turbidity, $\mathrm{pH}$, and specific conductance. Water levels are measured before each well is sampled.

\subsection{References}

Atomic Energy Act of 1954. As amended, Ch. 1073, 68 Stat. 919, 42 USC 2011 et seq.

Comprehensive Environmental Response, Compensation, and Liability Act. 1980. Public Law 96-510, as amended, 94 Stat. 2767, 42 USC 9601 et seq.

DOE - U.S. Department of Energy. 2002. Environmental Monitoring Plan United States Department of Energy Richland Operations Office. DOE/RL-91-50, Rev. 3, U.S. Department of Energy, Richland, Washington.

Hartman MJ, WD Webber, and LF Morasch (eds.). 2005. Hanford Site Groundwater Monitoring for Fiscal Year 2004. PNNL-15070, Pacific Northwest National Laboratory, Richland, Washington. 
Resource Conservation and Recovery Act. 1976. Public Law 94-580, as amended, 90 Stat. 2795, 42 USC 6901 et seq.

WAC 173-216. Waste Discharge Permit Program. Washington Administrative Code, Olympia, Washington. 


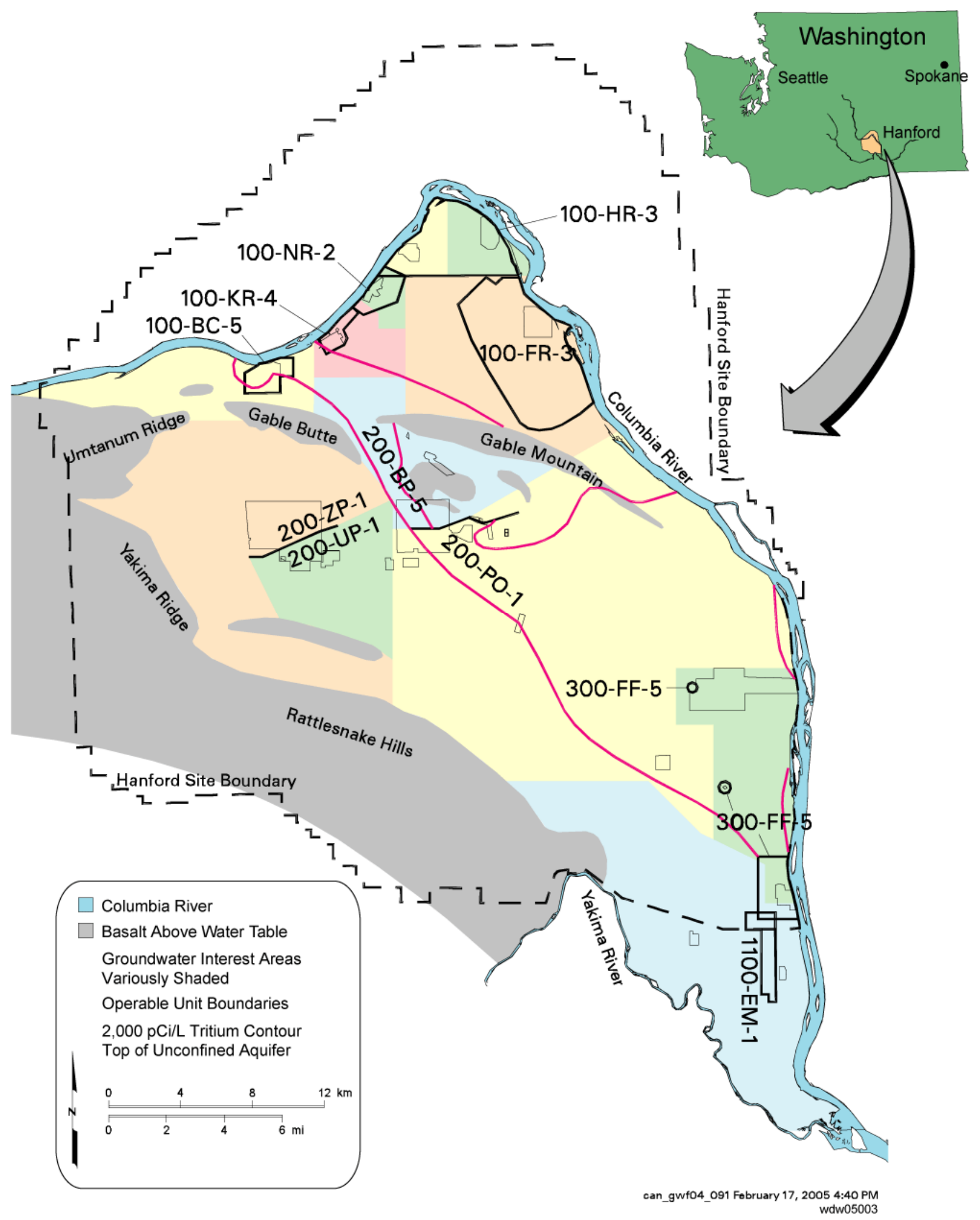

Figure 1. Hanford Site Groundwater Interest Areas 



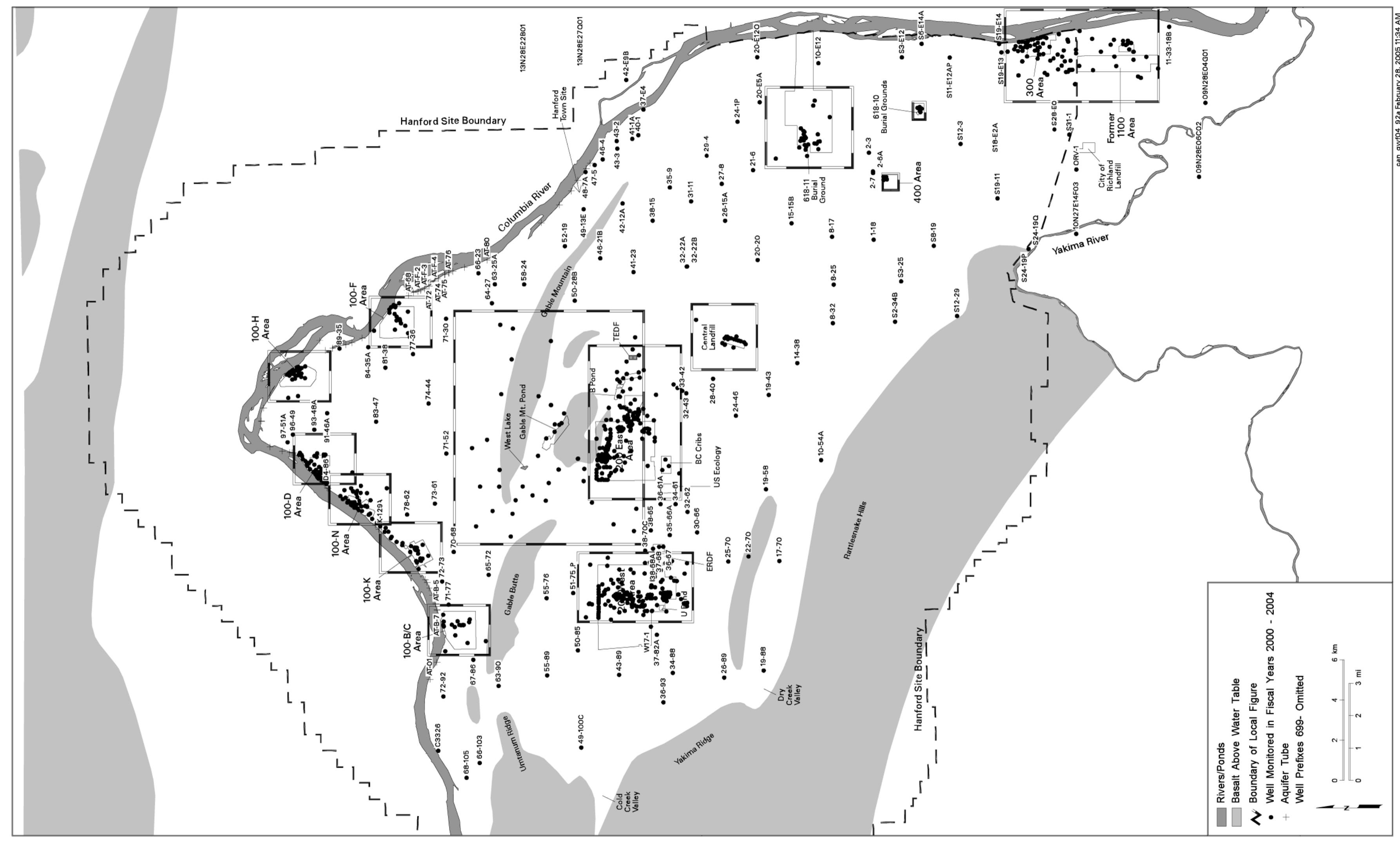




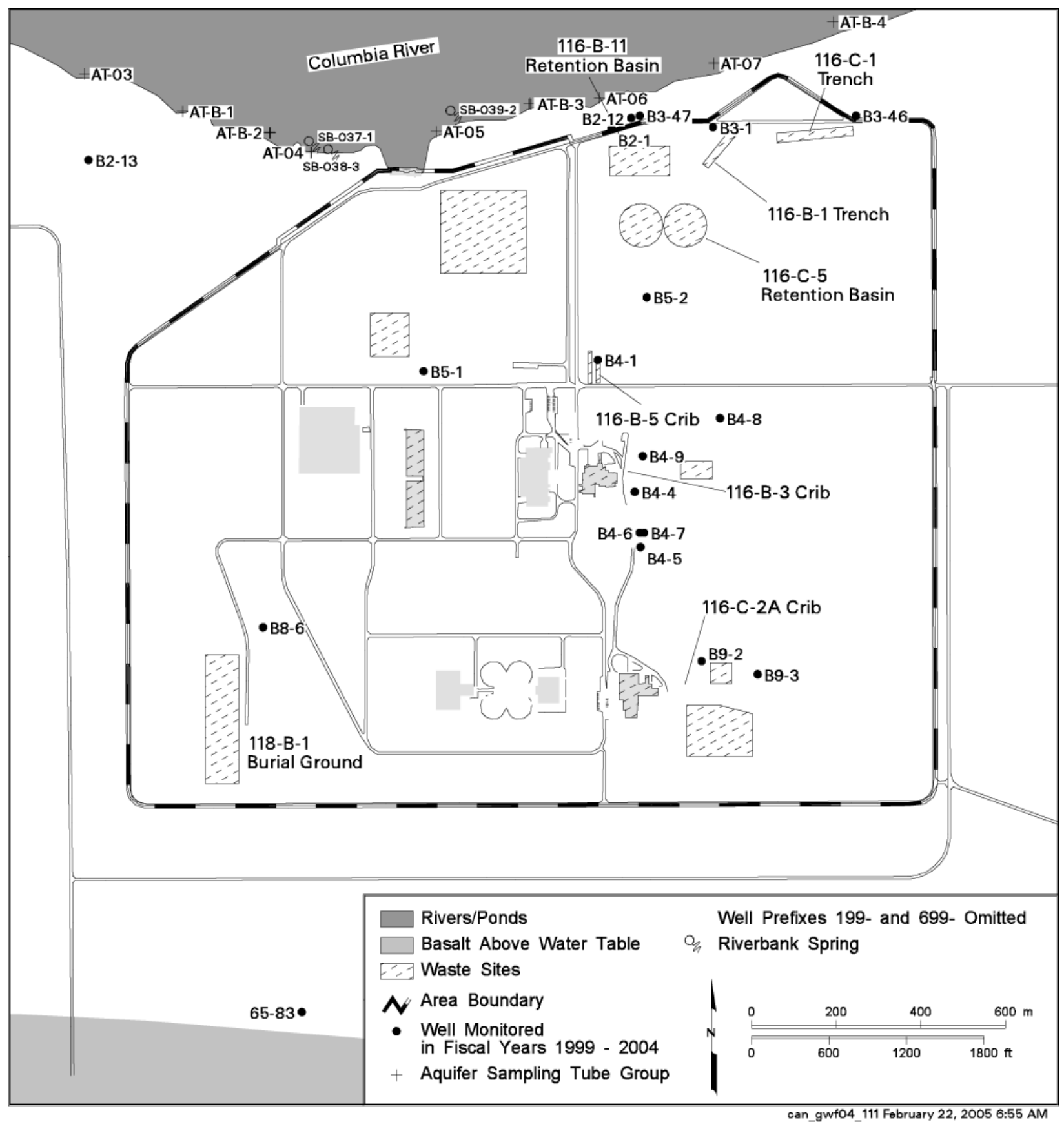

Figure 3. Groundwater Monitoring Wells in the 100-B/C Area 


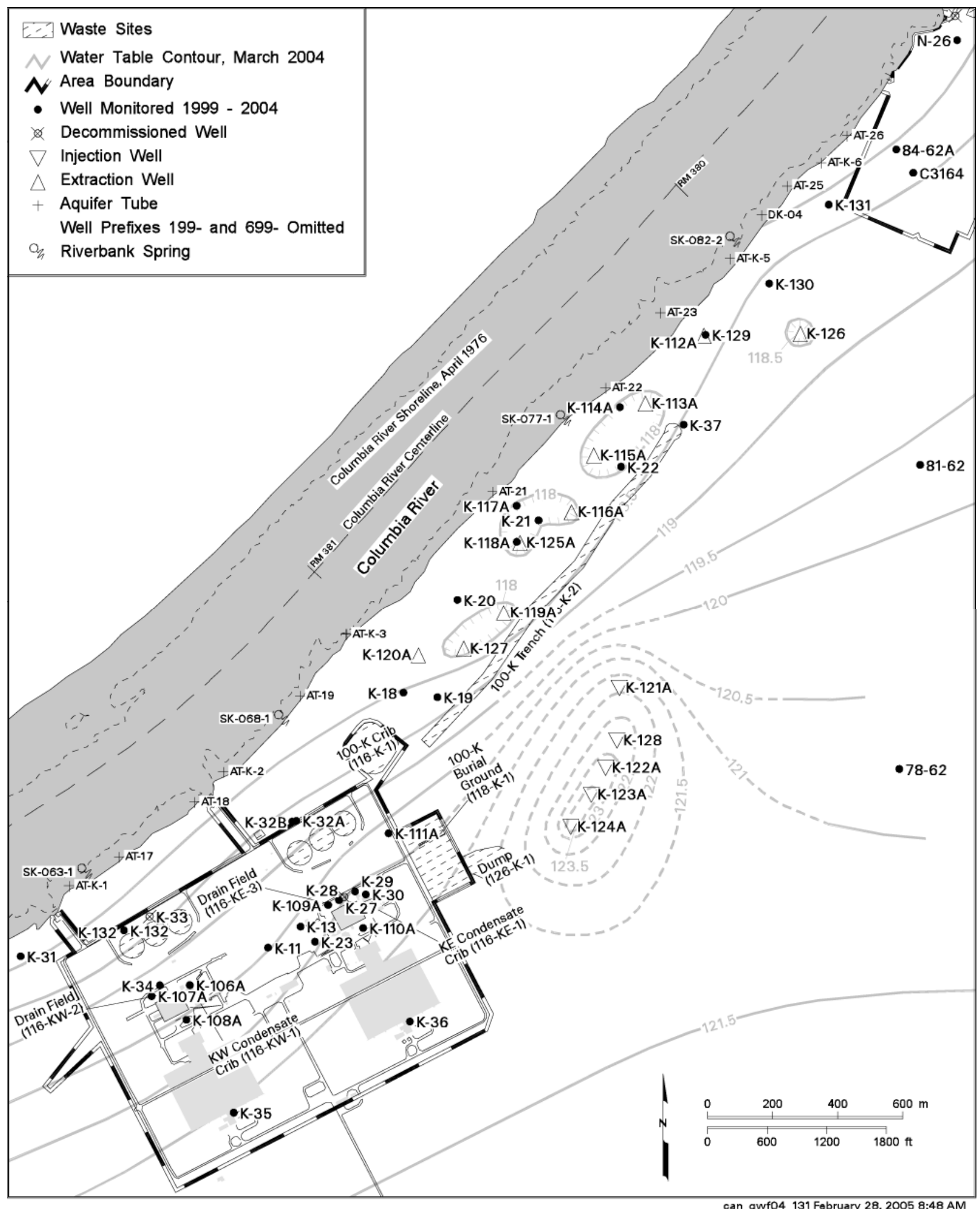

Figure 4. Groundwater Monitoring Wells in the 100-K Area 


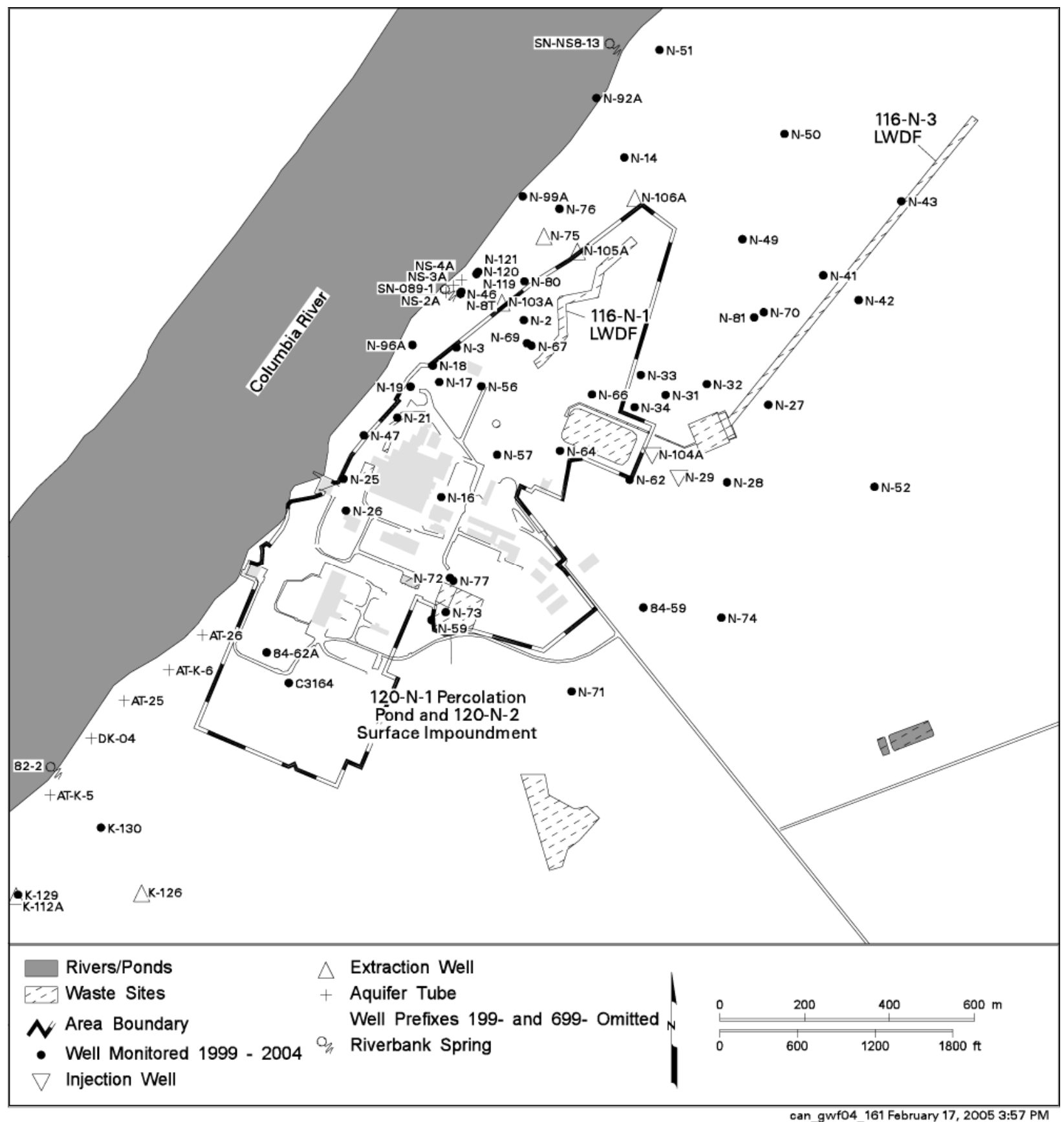

Figure 5. Groundwater Monitoring Wells in the 100-N Area 


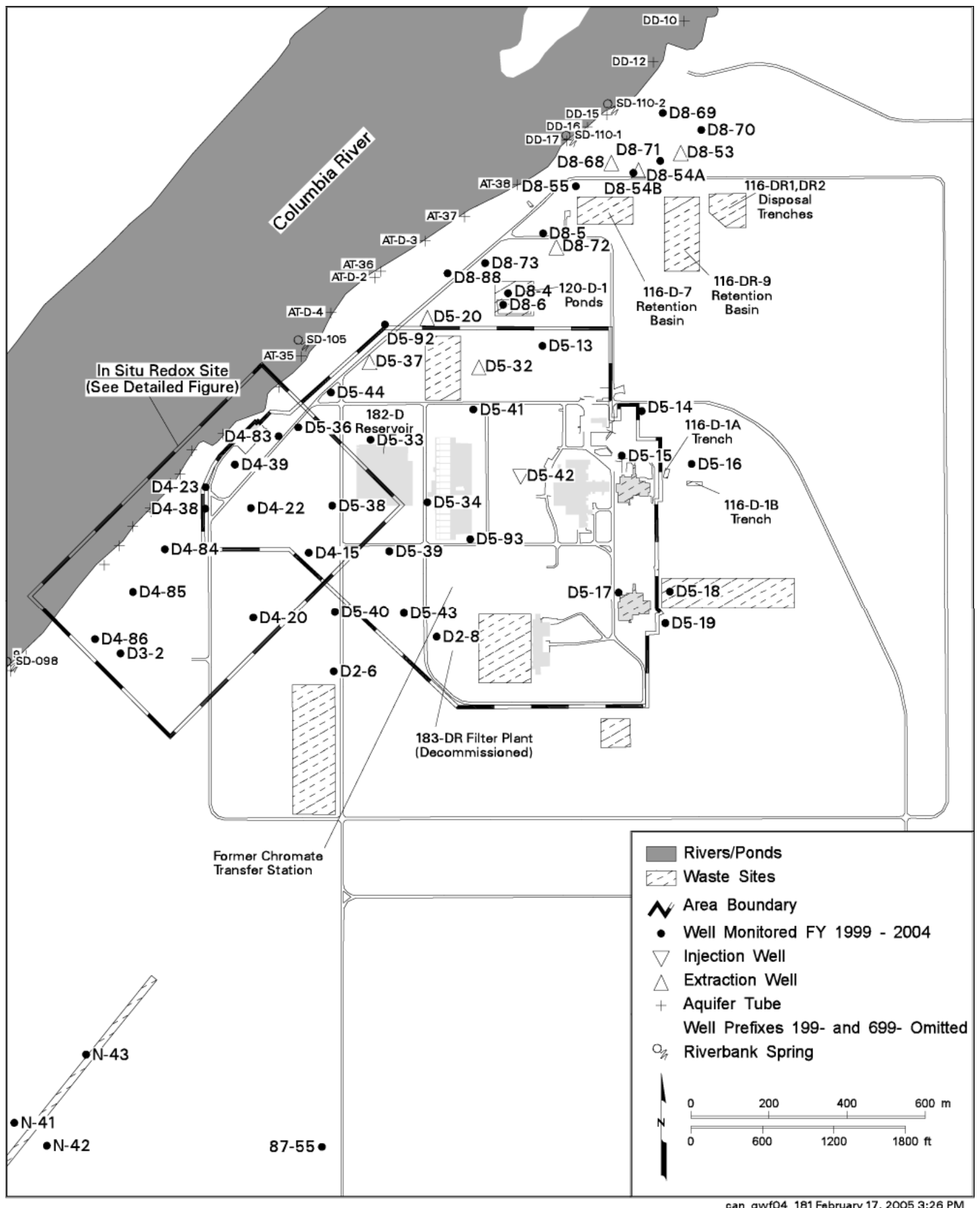

Figure 6. Groundwater Monitoring Wells in the 100-D Area 


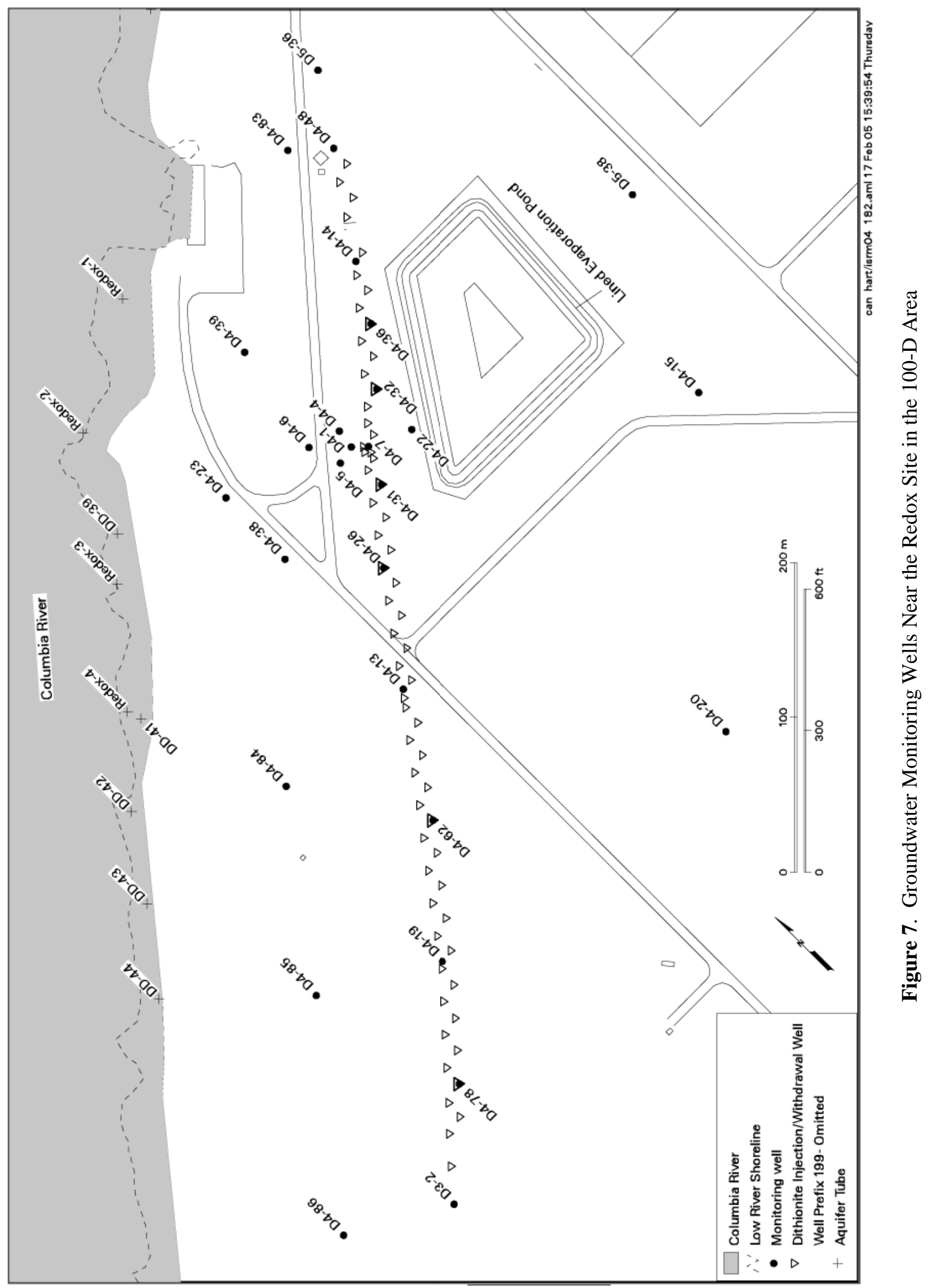




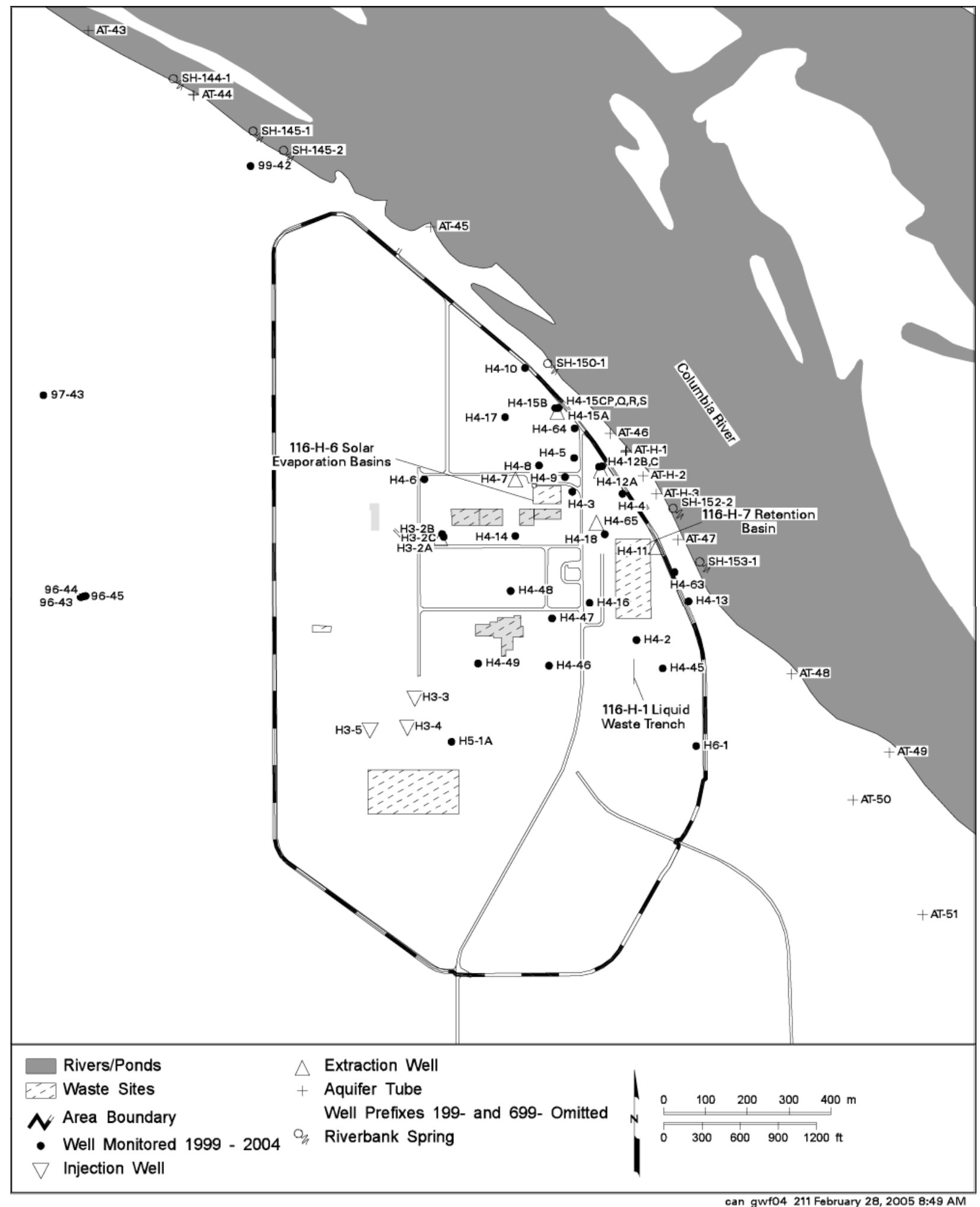

Figure 8. Groundwater Monitoring Wells in the 100-H Area 


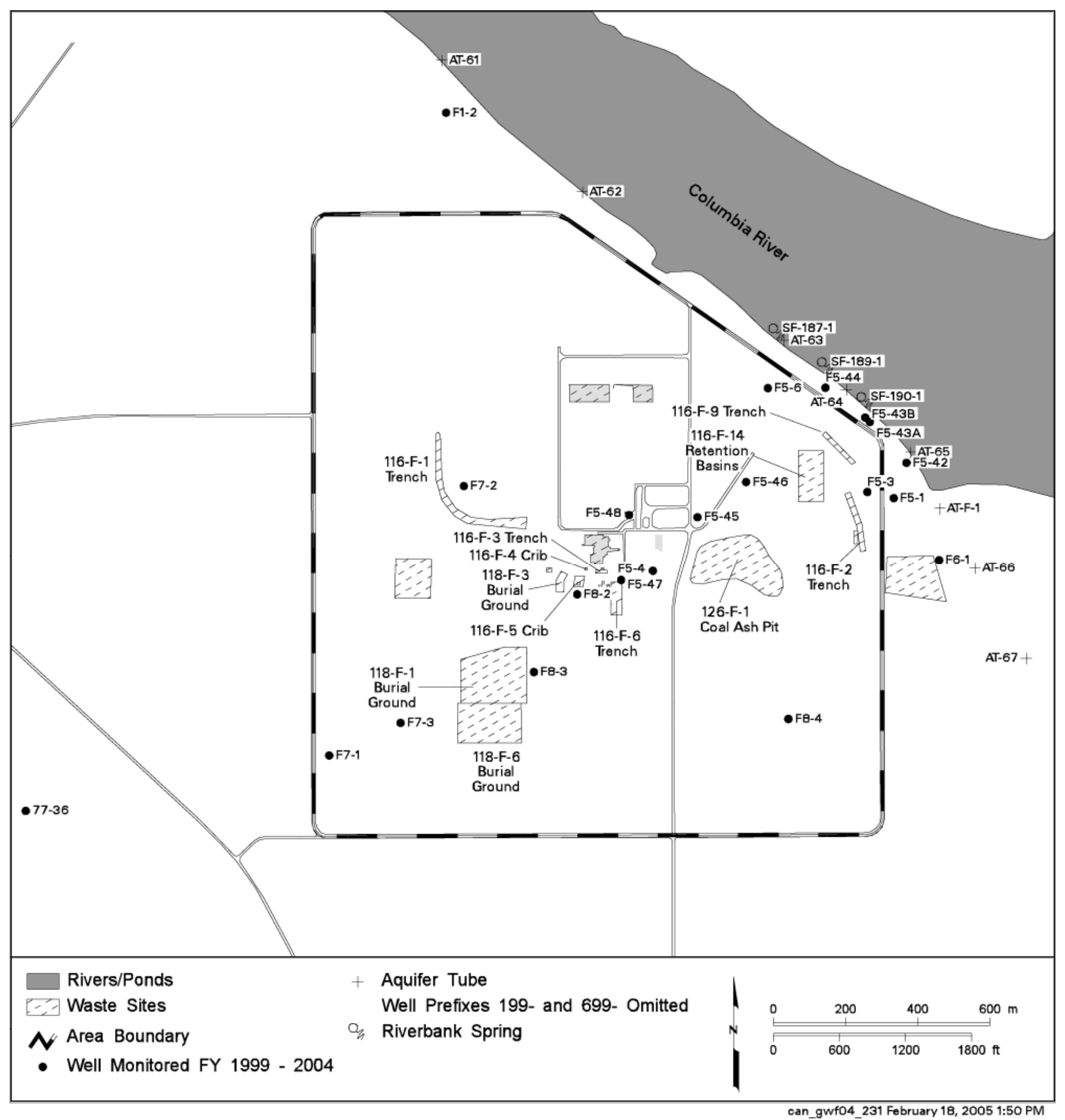

Figure 9. Groundwater Monitoring Wells in the 100-F Area 



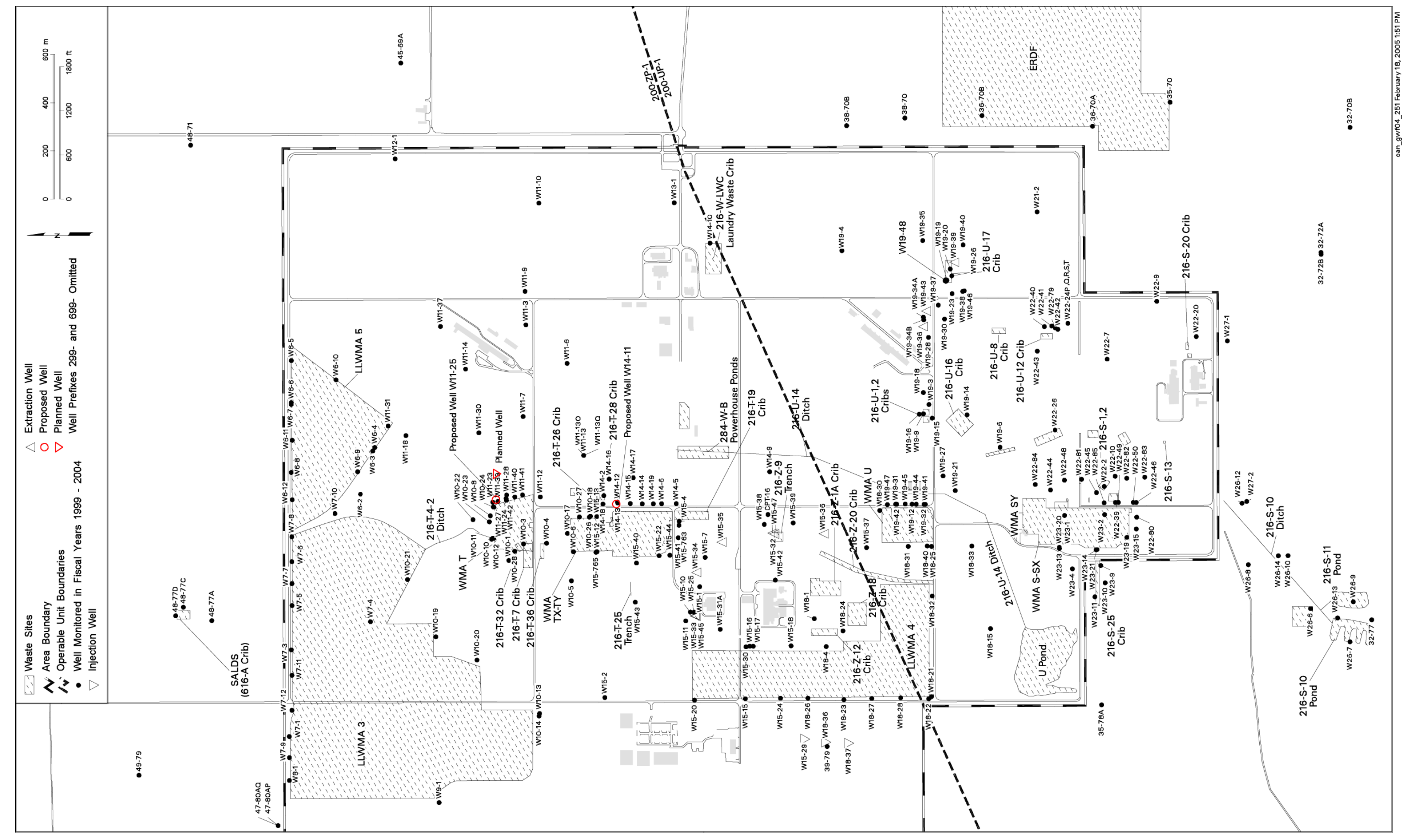




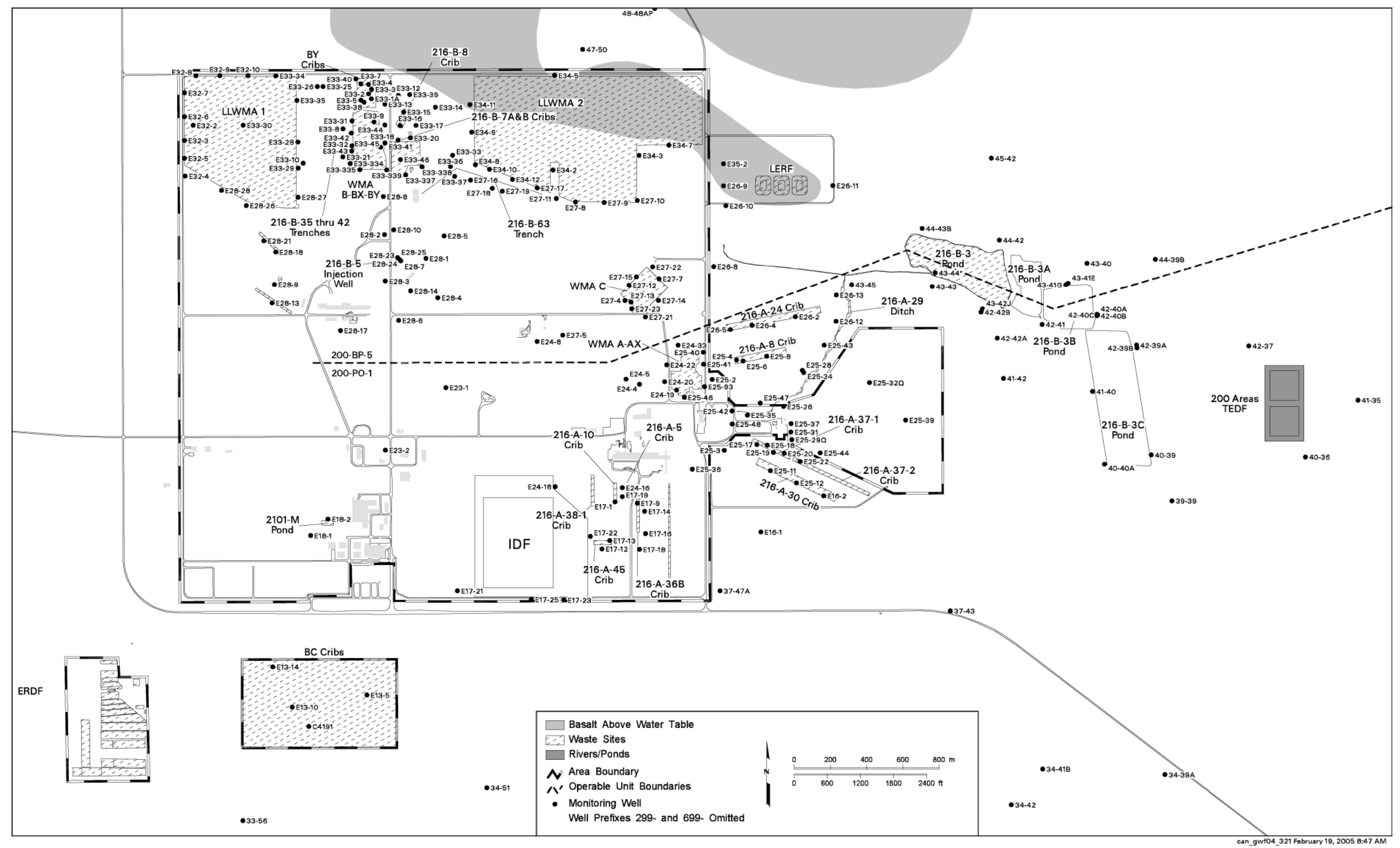

Figure 11. Groundwater Monitoring Wells in the 200 East Area

19 


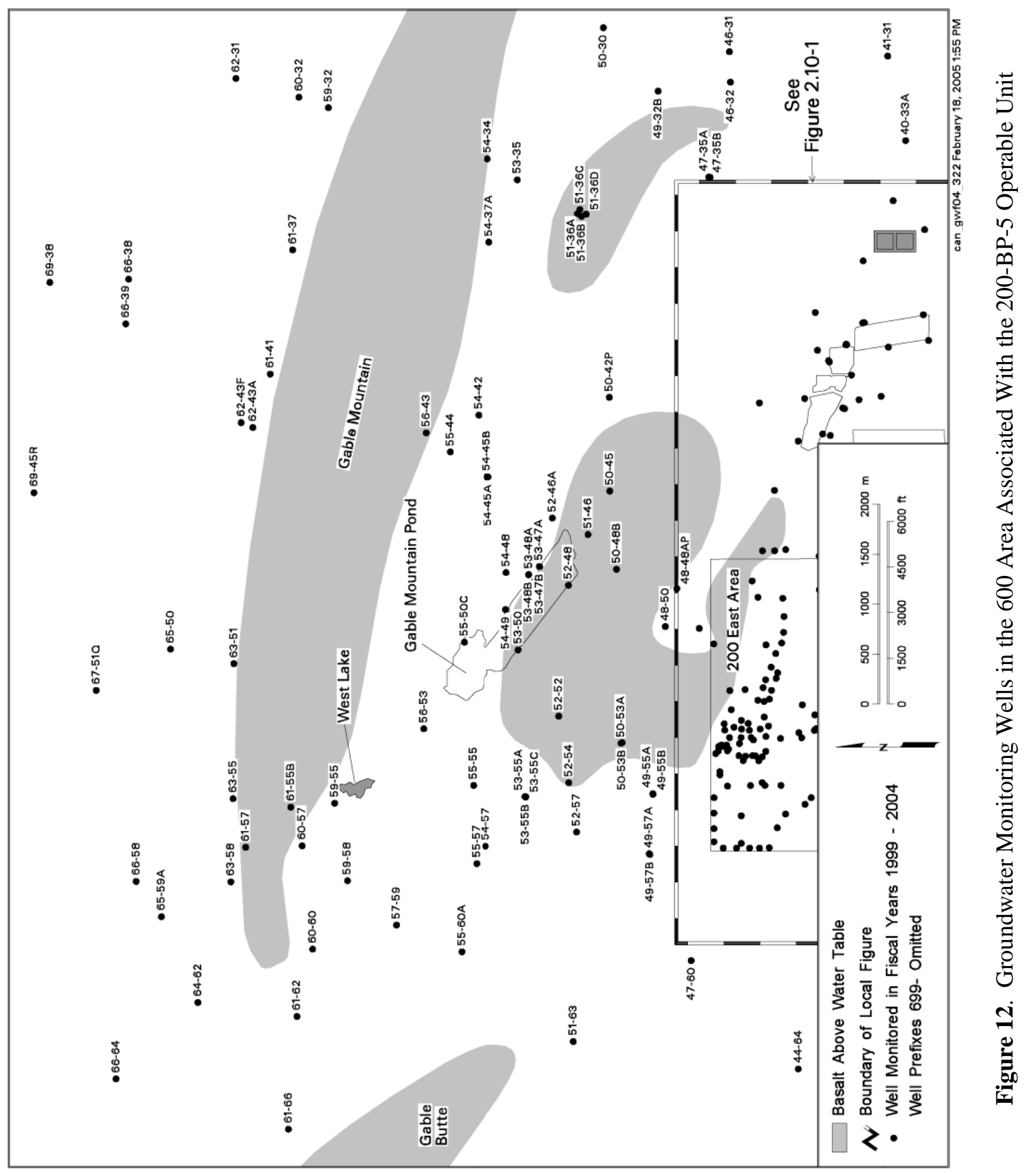




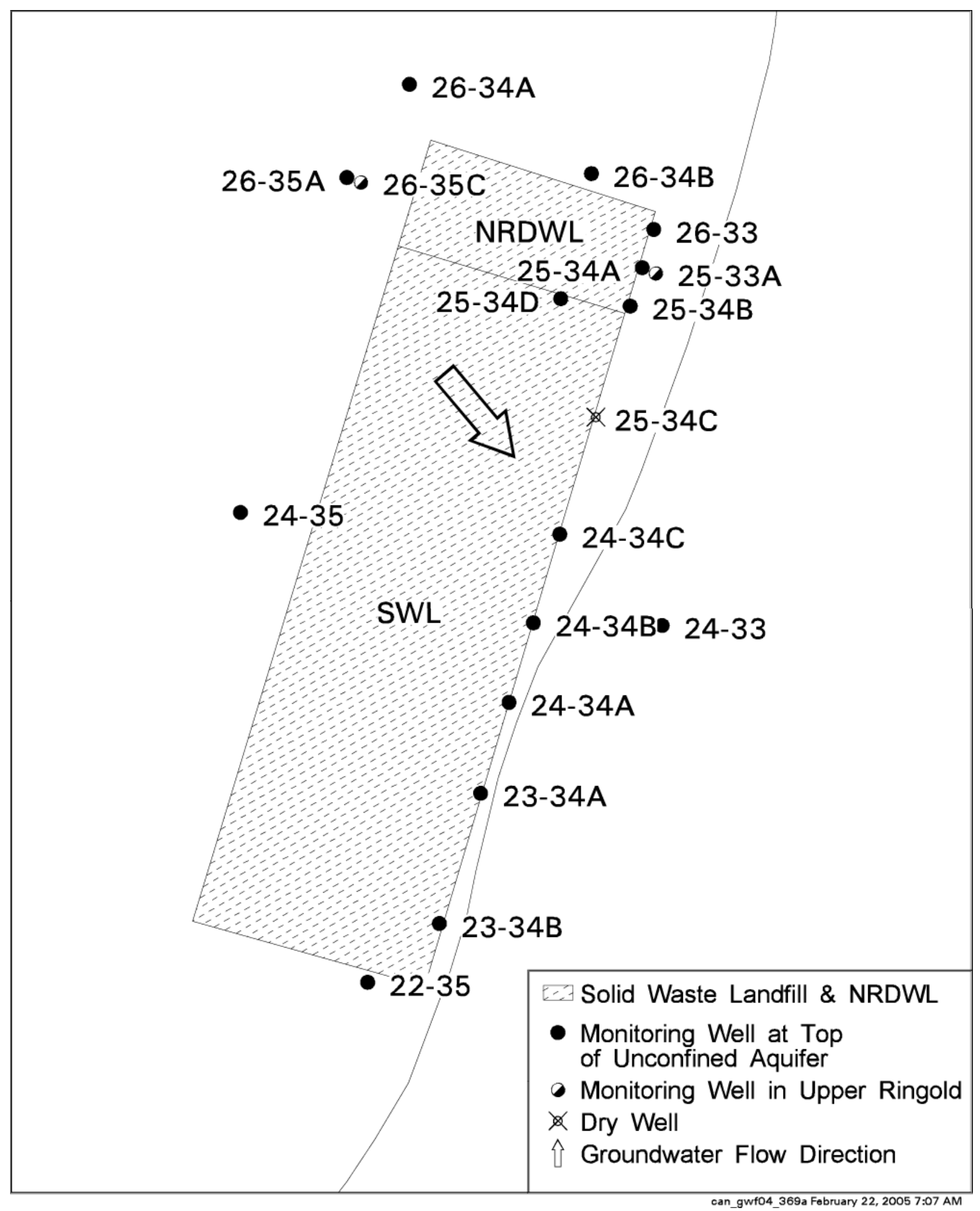

Figure 13. Groundwater Monitoring Wells at the Central Landfill 


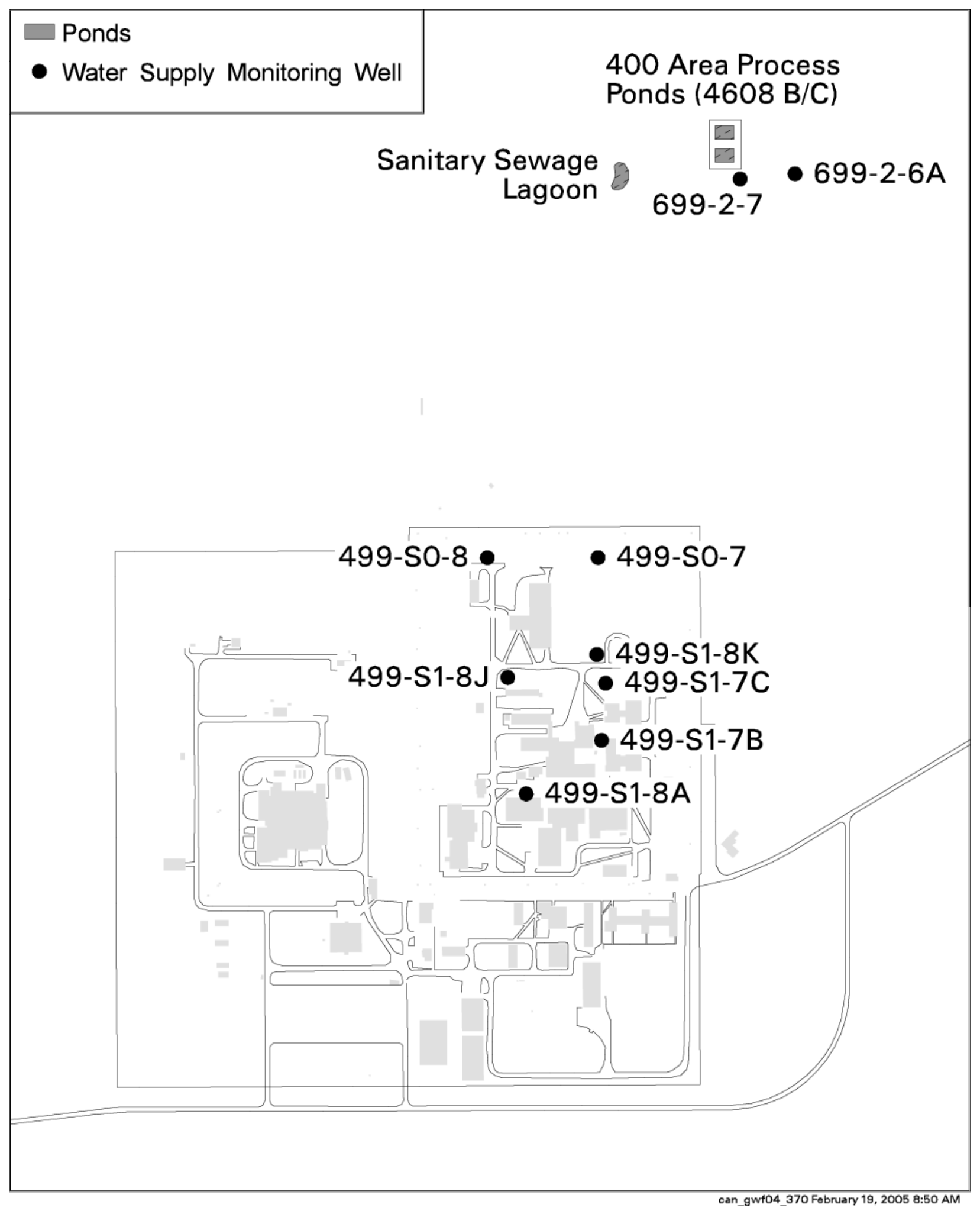

Figure 14. Groundwater Monitoring Wells in the 400 Area 

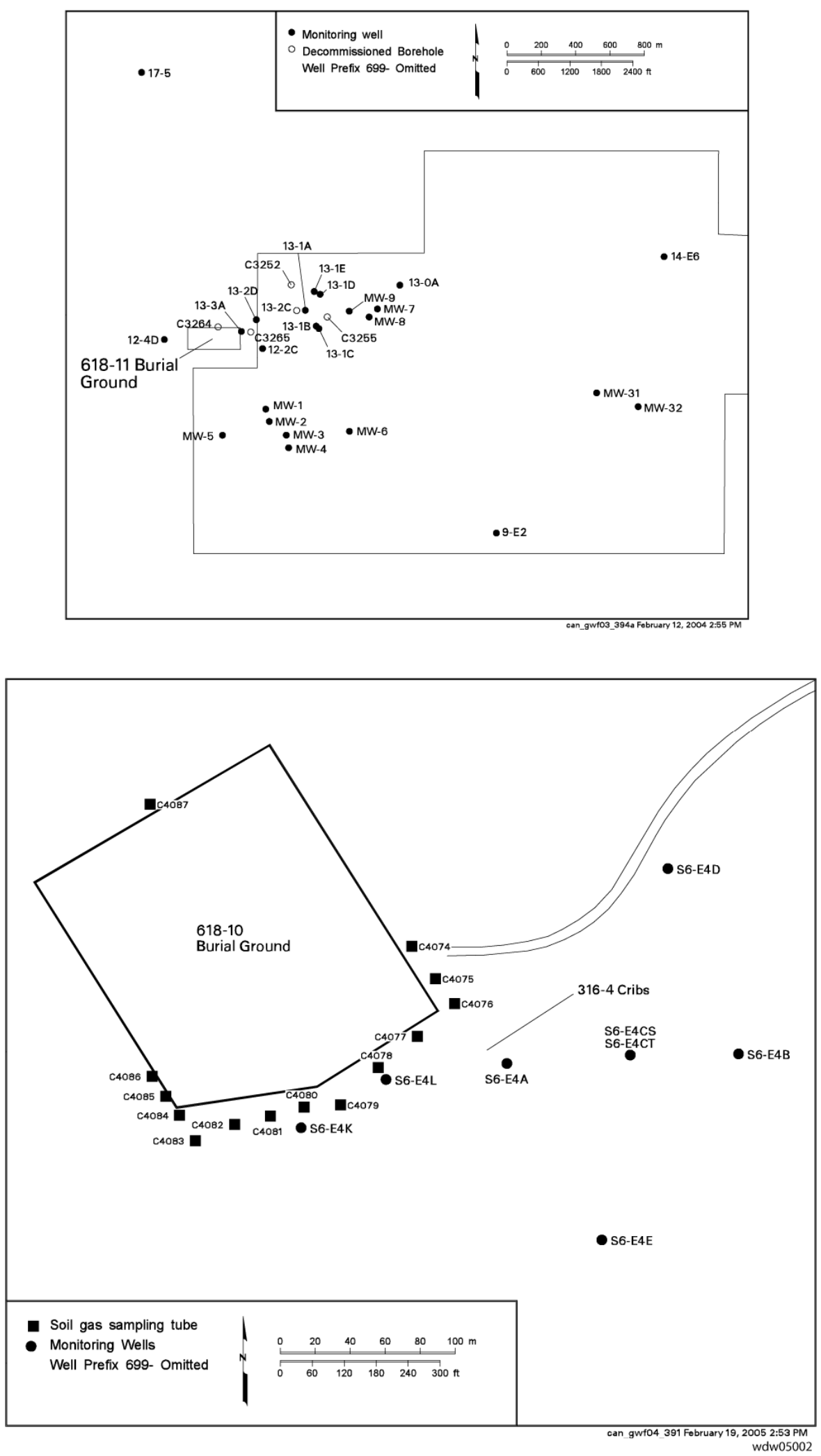

Figure 15. Groundwater Monitoring Wells at the 618-10 and 618-11 Burial Grounds 


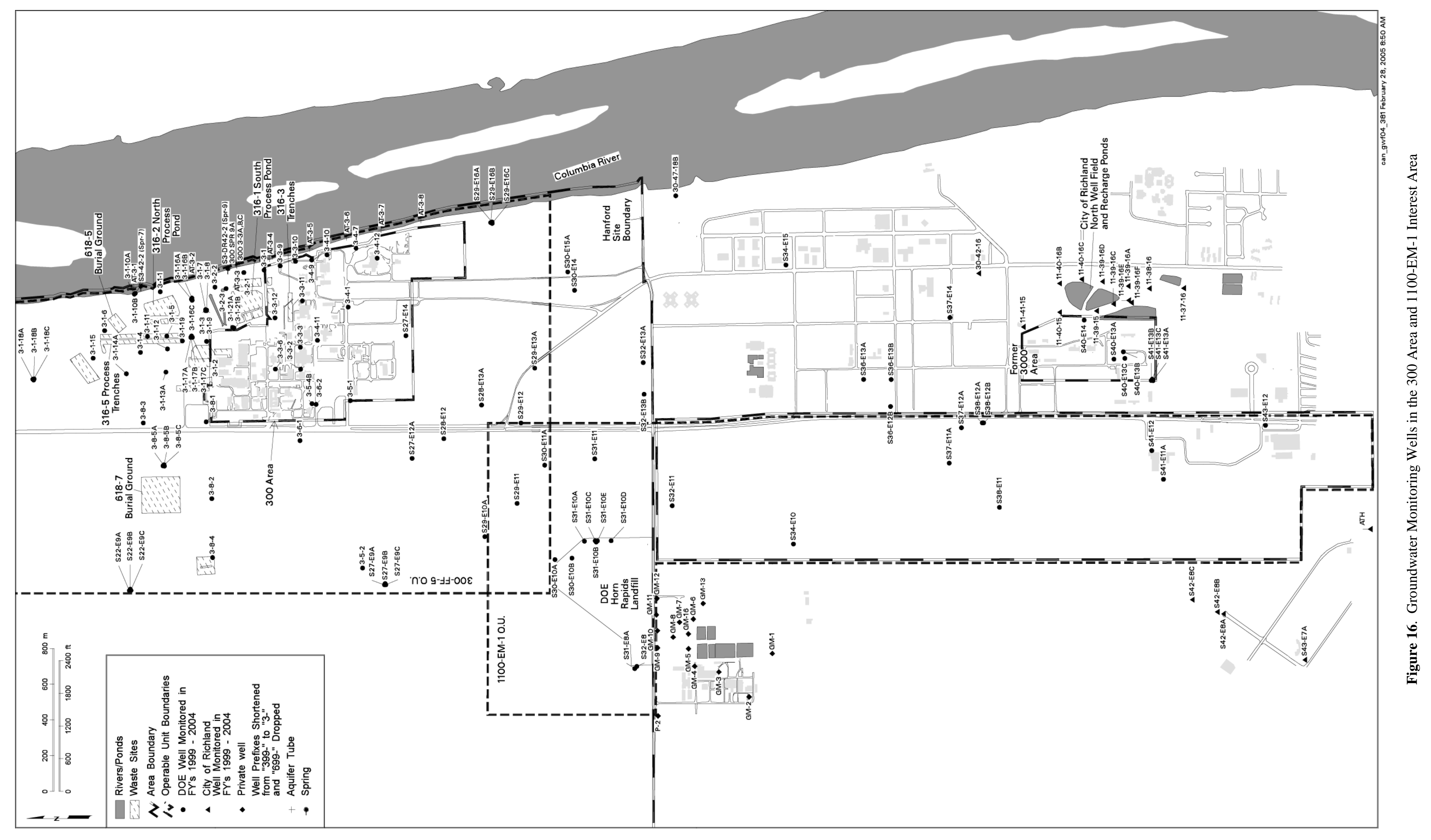


Appendix

\section{Table of Wells and Constituents}





\title{
Appendix A
}

\section{Table of Wells and Constituents}

This table of wells and constituents was constructed by querying the Hanford Groundwater Performance Assessment Project's (groundwater project) schedule database. This table was constructed mid-way through FY 2005 and includes changes that were made to the baseline schedule, such as added sampling events (e.g., to confirm questionable results or critical mean exceedance) or cancelled sampling events (e.g., removing dry wells or reflecting plan revisions). A version of this schedule is available on the groundwater project's website (http://groundwater.pnl.gov) and is updated periodically to reflect schedule changes.

\section{A.1 Table Key}

\author{
Program \\ CERCLA Comprehensive Environmental Response, Compensation, and Liability Act of 1980 \\ (Monitoring associated with interim remedial actions.) \\ DOH Washington State Department of Health (Samples collected for analysis by the \\ Washington State Department of Health are for independent verification and are not \\ part of the DOE programs. These samples are included in this table for information \\ purposes only.) \\ LTMC Long-term CERCLA monitoring and CERCLA remedial investigation/feasibility \\ study investigations. \\ PA Performance assessment under AEA \\ RCRA Resource Conservation and Recovery Act of 1976 \\ SURV Site-wide surveillance (AEA) \\ TUBE Aquifer sampling tubes
}

\section{Proj_WMA (Project or Waste Management Area)}

100HR3IAM(1) or (2) Interim action monitoring for the 100-HR-3 Operable Unit (1) near pump-and-treat systems and (2) throughout the operable unit

100KR4IAM(1) or (2) Interim action monitoring for the 100-KR-4 Operable Unit (1) near pump-and-treat systems and (2) throughout the operable unit

100NR2IAM

Interim action monitoring for the 100-NR-2 Operable Unit

11EM1-C

CERCLA monitoring for 1100-EM-1 Operable Unit

11EM1-City-S

Surveillance monitoring near the city of Richland for the 1100-EM-1 groundwater interest area

11EM1-S

Surveillance monitoring for the 1100-EM-1 groundwater interest area 
$1301 N$

$1324 \mathrm{~N}$

1325N

$183 \mathrm{H}$

1BC5-C

1FR3-C

1HR3-D-S

1HR3-H-S

1K-Basins

1KR4-S

1NR2-Rebound

1NR2-S

2BP5-C

2PO1-C

2UP1-C

2UP1-Rebound

2UP1-S

2ZP1-C

2ZP1-S

300-APT

3FF5-300-C

3FF5-300-S

3FF5-North-C

400

A-29

B-63

BASTL-CONF

BPOND

$\mathrm{DOH}$
1301-N Liquid Waste Disposal Facility

1324-N surface impoundment and 1324-NA percolation pond

1325-N Liquid Waste Disposal Facility

183-H evaporation basins

100-BC-5 Operable Unit and groundwater interest area

100-FR-3 Operable Unit and groundwater interest area

Surveillance monitoring for 100-HR-3-D groundwater interest area (west portion of 100-HR-3 Operable Unit)

Surveillance monitoring for 100-HR-3-H groundwater interest area (east portion of 100-HR-3 Operable Unit)

100-K storage basins

Surveillance monitoring for 100-KR-4 groundwater interest area

Monitoring in support of proposed rebound study at 100-NR-2 Operable Unit

Surveillance monitoring for 100-NR-2 groundwater interest area

200-BP-5 Operable Unit and groundwater interest area

200-PO-1 Operable Unit and groundwater interest area

200-UP-1 Operable Unit, including interim action

Sampling to support rebound study at 200-UP-1 pump-and-treat

Surveillance monitoring for 200-UP-1 groundwater interest area

200-ZP-1 Operable Unit, including interim action

Surveillance monitoring for 200-ZP-1 groundwater interest area

300 Area process trenches (316-5)

CERCLA monitoring for 300-FF-5 Operable Unit, 300 Area

Surveillance monitoring for 300-FF-5 Operable Unit, 300 Area

CERCLA monitoring for north portion of 300-FF-5 Operable Unit

400 Area

216-A-29 ditch

216-B-63 trench

Basalt-confined aquifer

216-B-3 pond

Washington State Department of Health (see Program key) 
Environmental Restoration Disposal Facility - sampling for facility performance for Bechtel Hanford, Inc. (expected to transition to Washington Closure Group)

ISRM

In situ redox manipulation system

LERF

Liquid Effluent Retention Facility

LLBG(1) through (4)

Low-level burial grounds, Waste Management Areas 1 through 4 (RCRA monitoring)

LLBG(1) through (4)-PA

Low-level burial grounds, Waste Management Areas 1 through 4 (AEA performance assessment monitoring)

NRDW Nonradioactive Dangerous Waste Landfill

PUREX Plutonium-Uranium Extraction Plant cribs

S-10

216-S-10 pond and ditch

SST(A), (B), (C), (SSX), Single-shell tank waste management areas A-AX, B-BX-BY, C, S-SX, (T), (TX/TY) or $(\mathrm{U}) \quad \mathrm{T}, \mathrm{TX}-\mathrm{TY}$, and $\mathrm{U}$

SWL Solid Waste Landfill

TUBE Aquifer sampling tubes

$\mathrm{U}-12$ 216-U-12 crib

\section{Constituent Abbreviations}

$\begin{array}{ll}\text { As } & \text { arsenic } \\ \text { COD } & \text { chemical oxygen demand } \\ \text { DO } & \text { dissolved oxygen } \\ \text { filt } & \text { filtered samples } \\ \text { Hex Cr } & \text { hexavalent chromium } \\ \text { Hg } & \text { mercury } \\ \text { ICP } & \text { inductively couple plasma method } \\ \text { Pb } & \text { lead } \\ \text { PCB } & \text { polychlorinated biphenyls } \\ \text { REDOX } & \text { reduction-oxidation potential } \\ \text { TDS } & \text { total dissolved solids } \\ \text { TOC } & \text { total organic carbon } \\ \text { TOX } & \text { total organic halides } \\ \text { TPH } & \text { total petroleum hydrocarbons } \\ \text { U-iso } & \text { isotopic uranium } \\ \text { Uranium } & \text { total uranium } \\ \text { VOA } & \text { volatile organic analyses }\end{array}$




\section{A.2 References}

Atomic Energy Act of 1954. As amended, Ch. 1073, 68 Stat. 919, 42 USC 2011 et seq.

Comprehensive Environmental Response, Compensation, and Liability Act. 1980. Public Law 96-510, as amended, 94 Stat. 2767, 42 USC 9601 et seq.

Resource Conservation and Recovery Act. 1976. Public Law 94-580, as amended, 90 Stat. 2795, 42 USC 6901 et seq. 


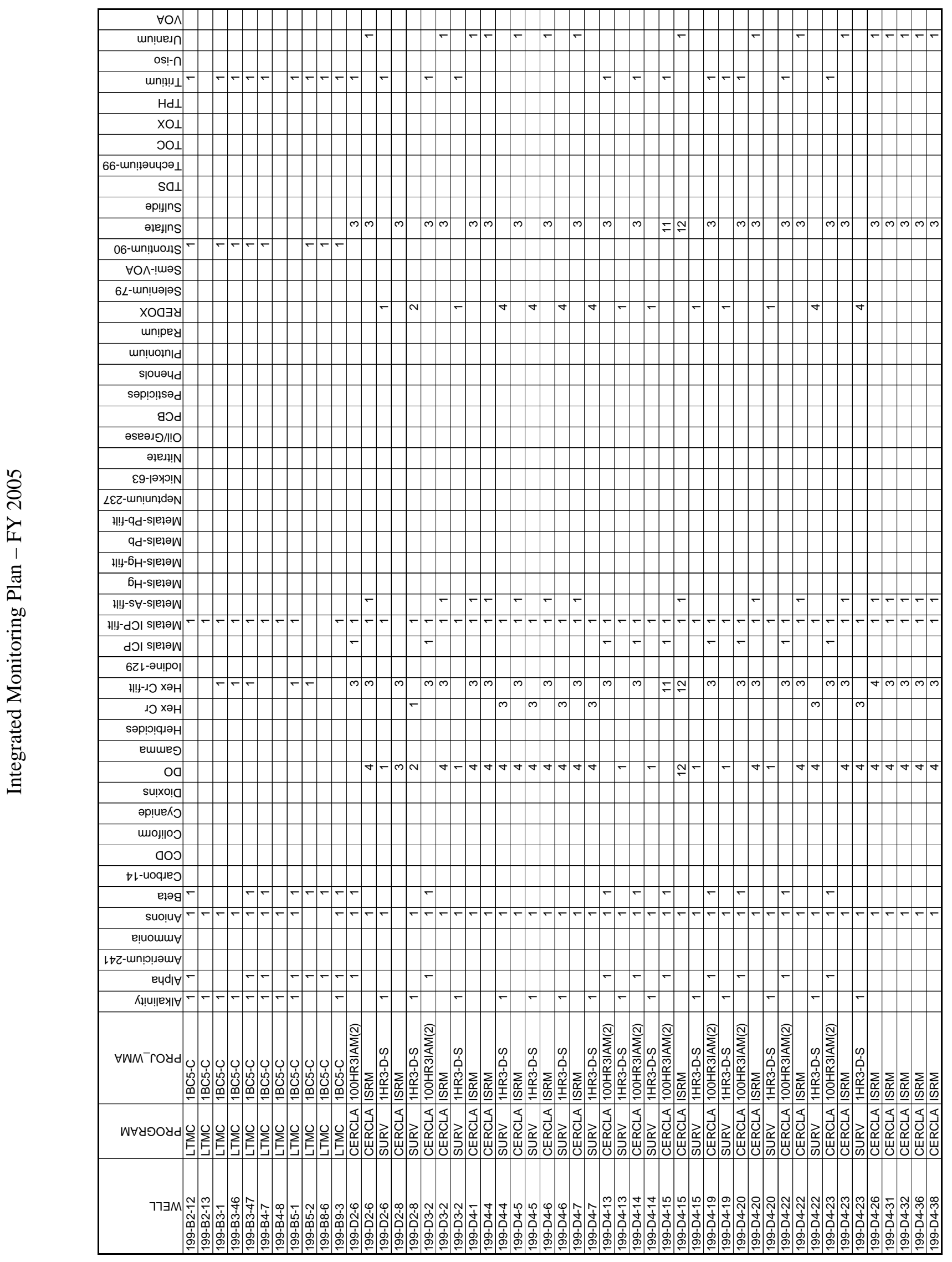

A. 5 


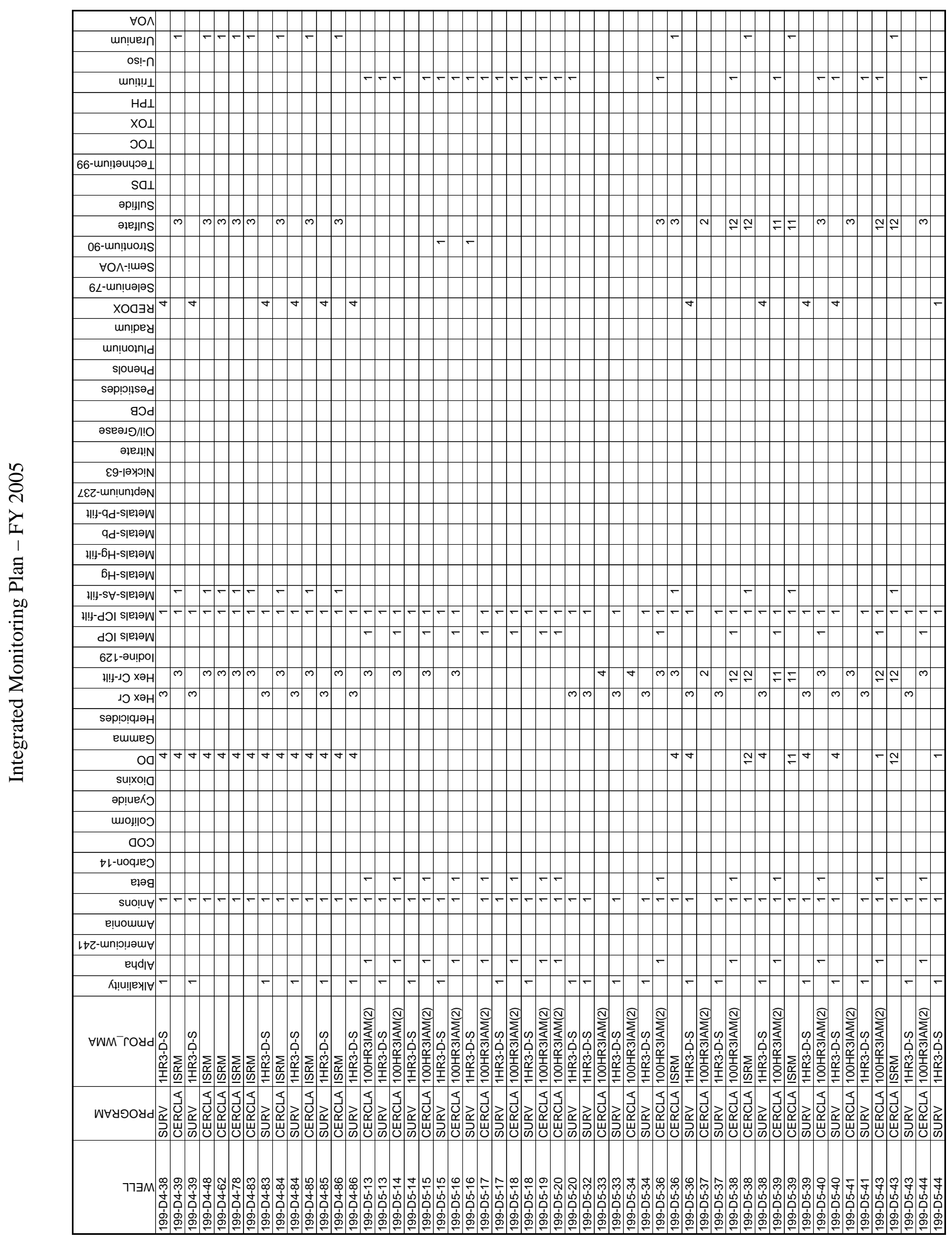




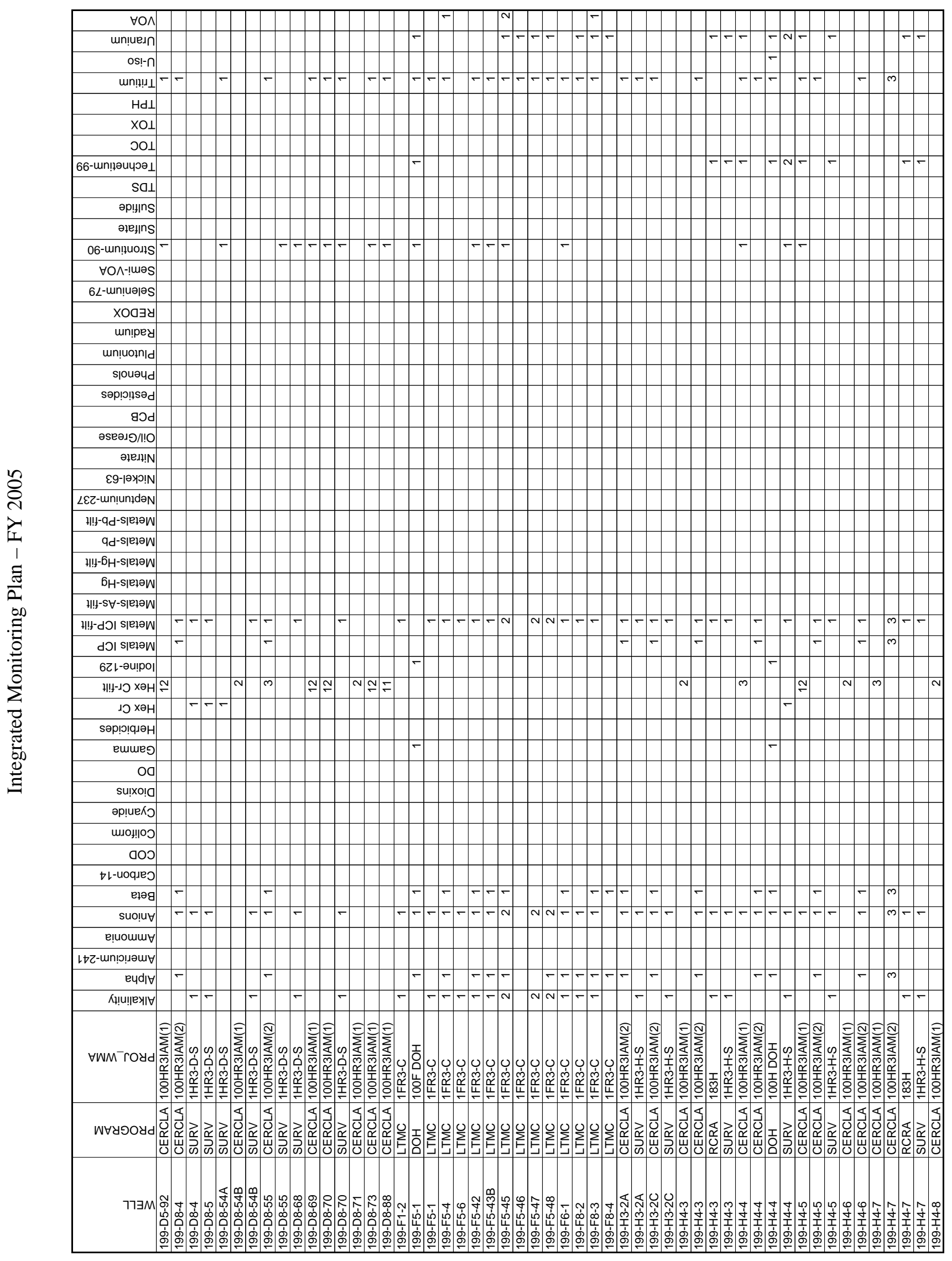

A. 7 


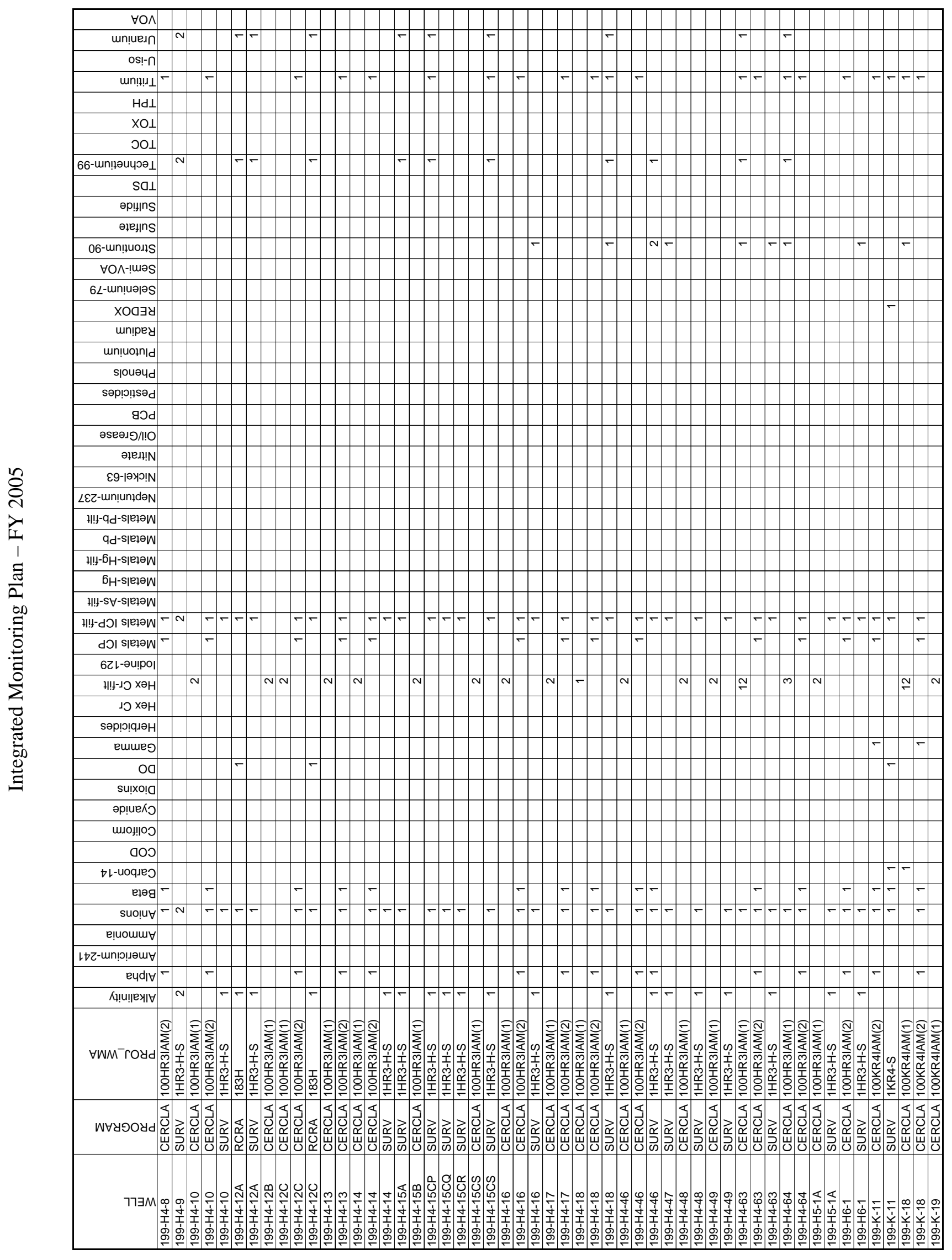




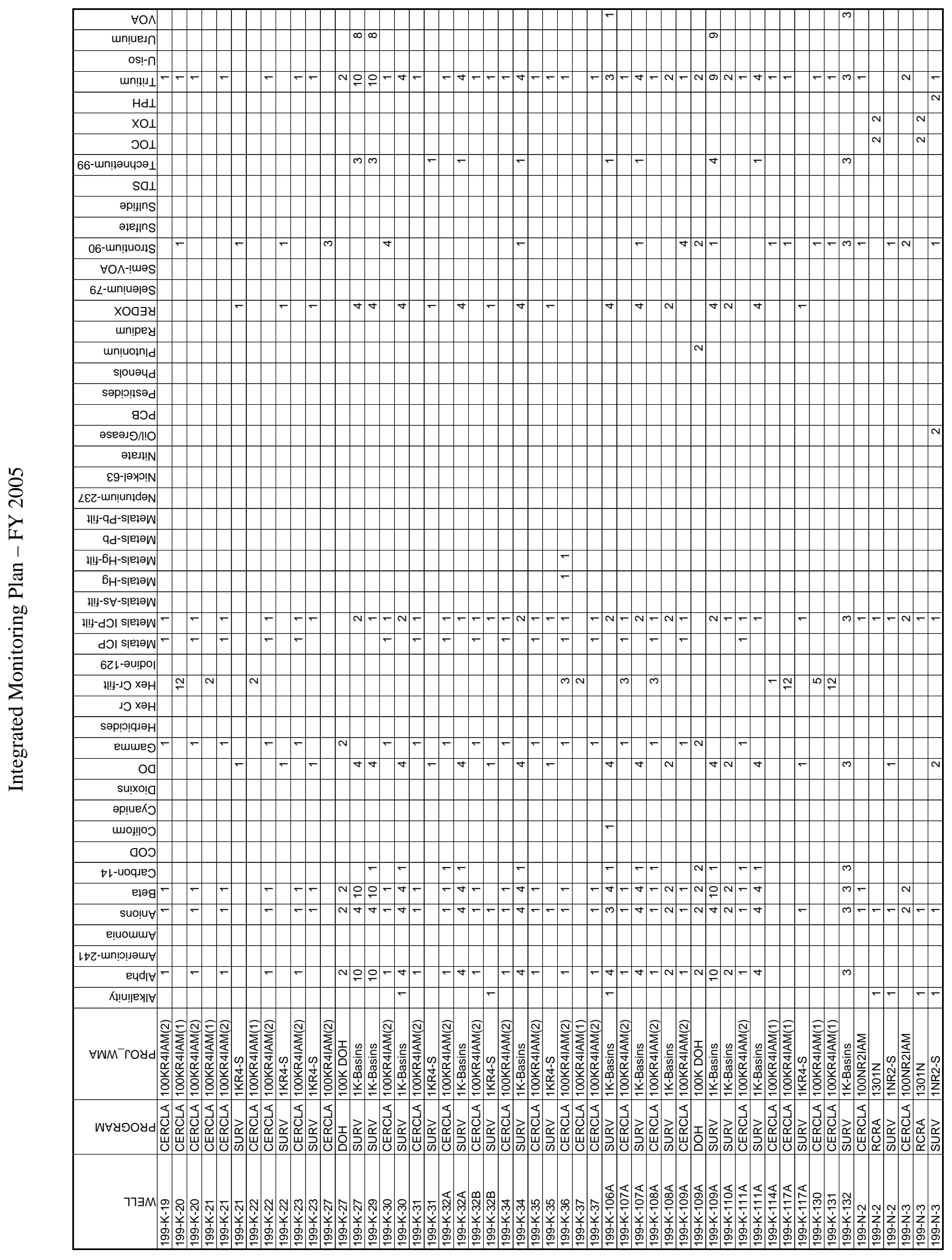




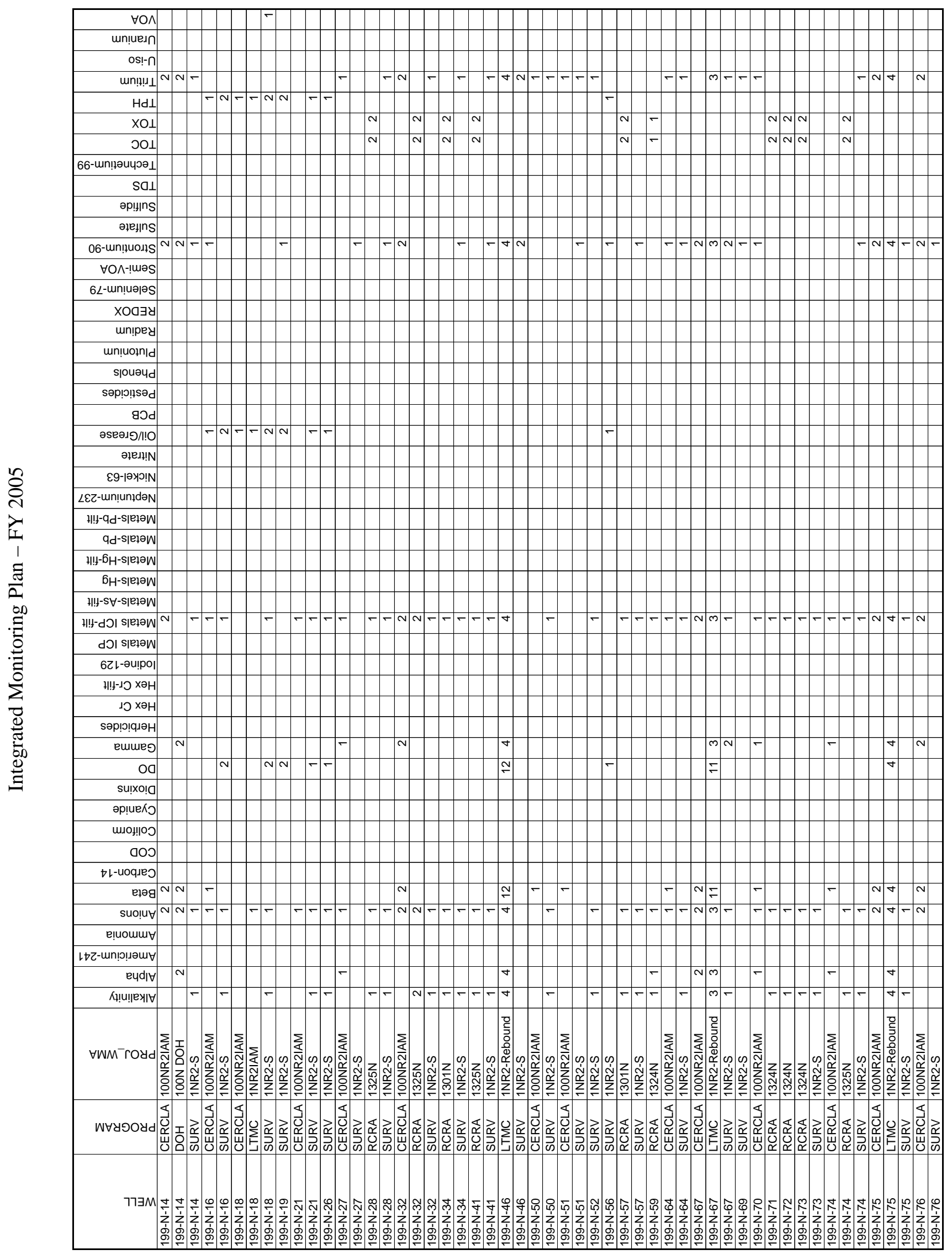




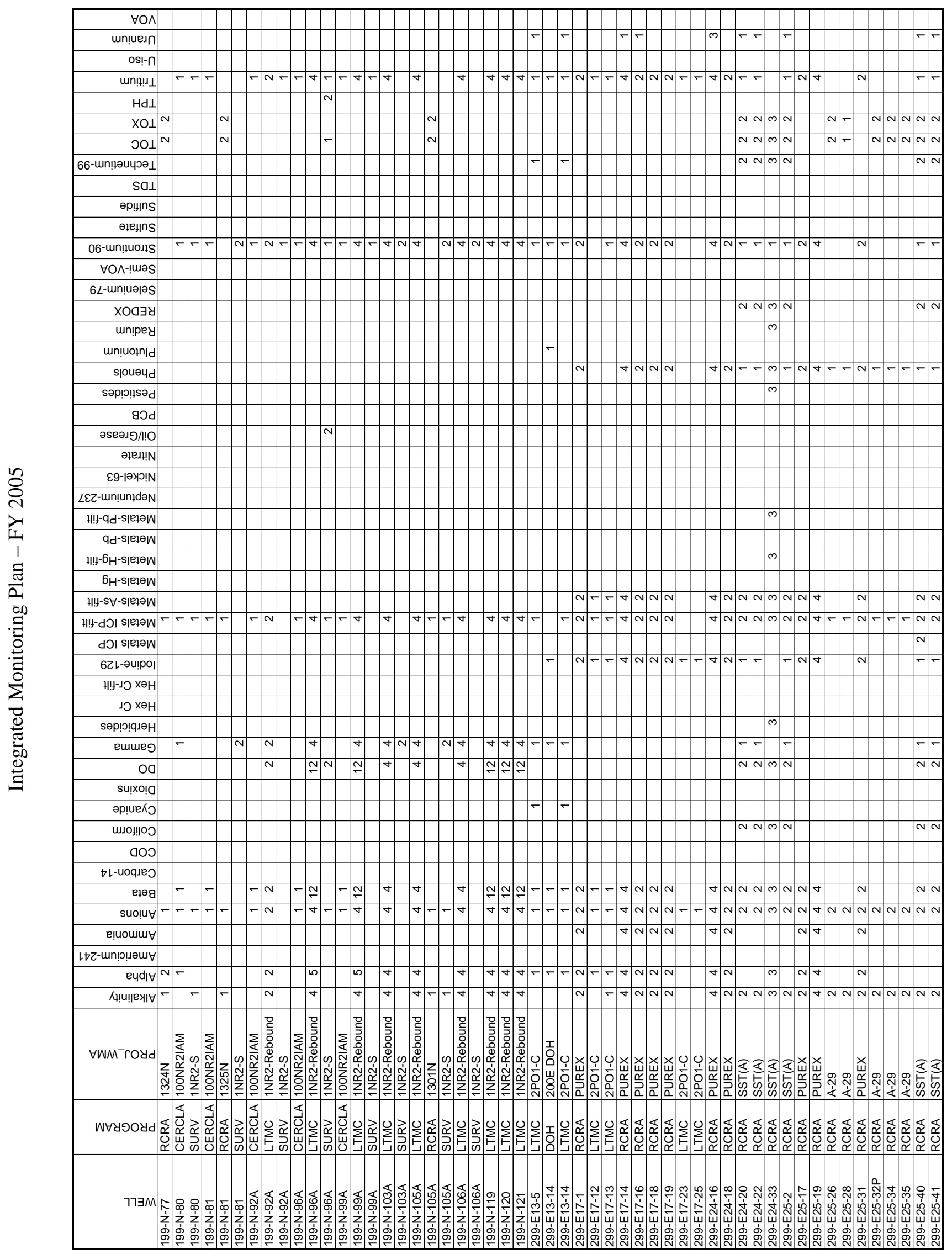




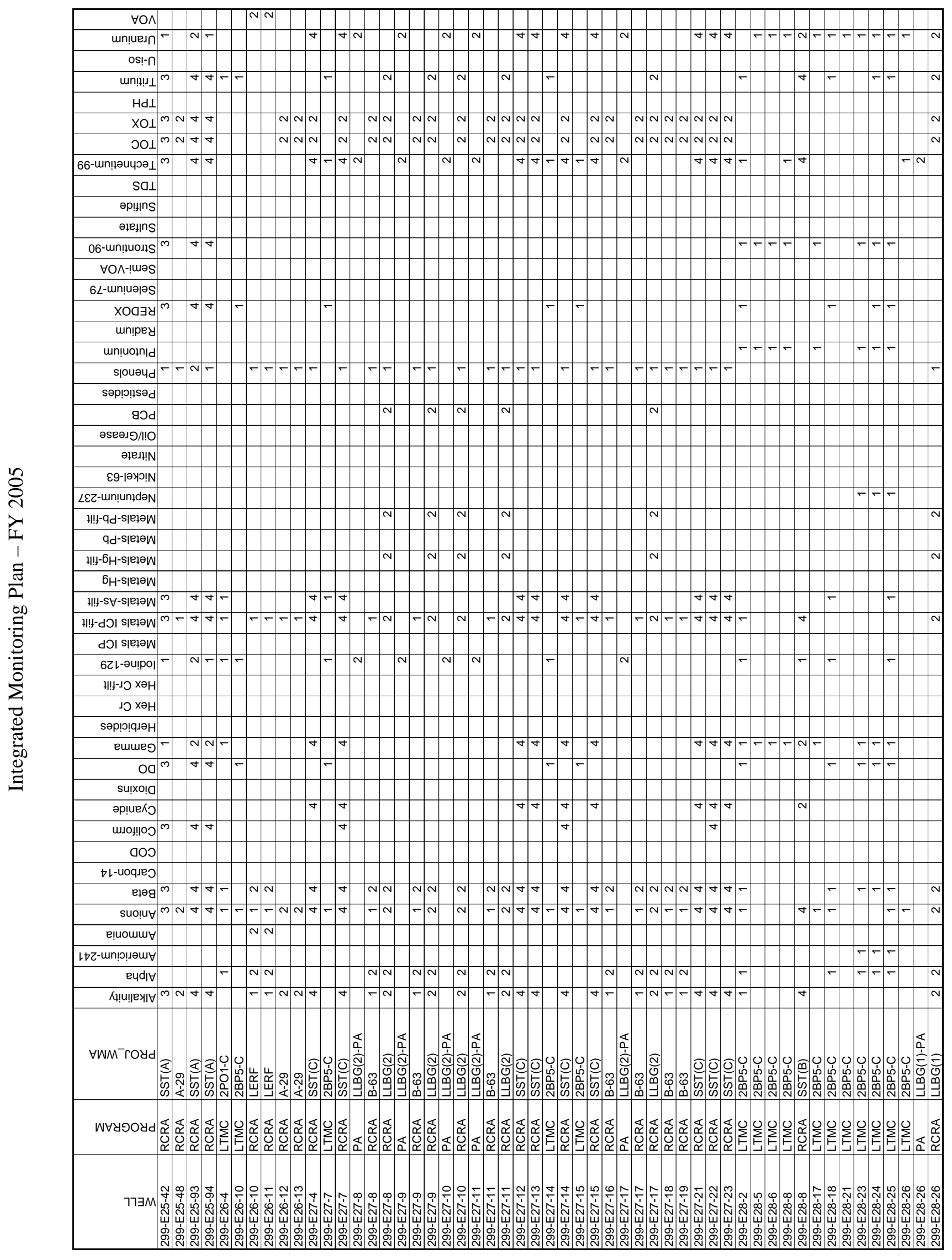




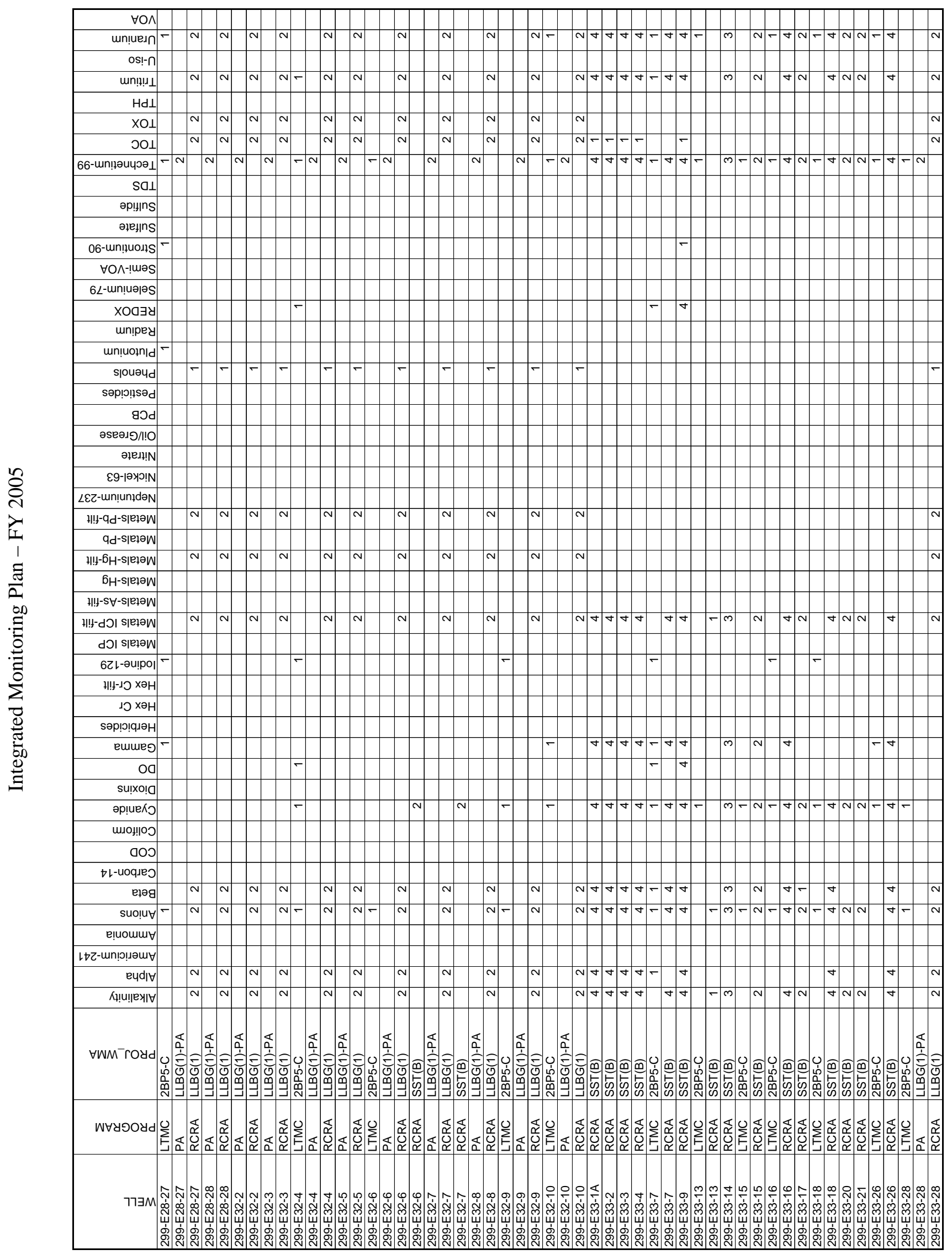




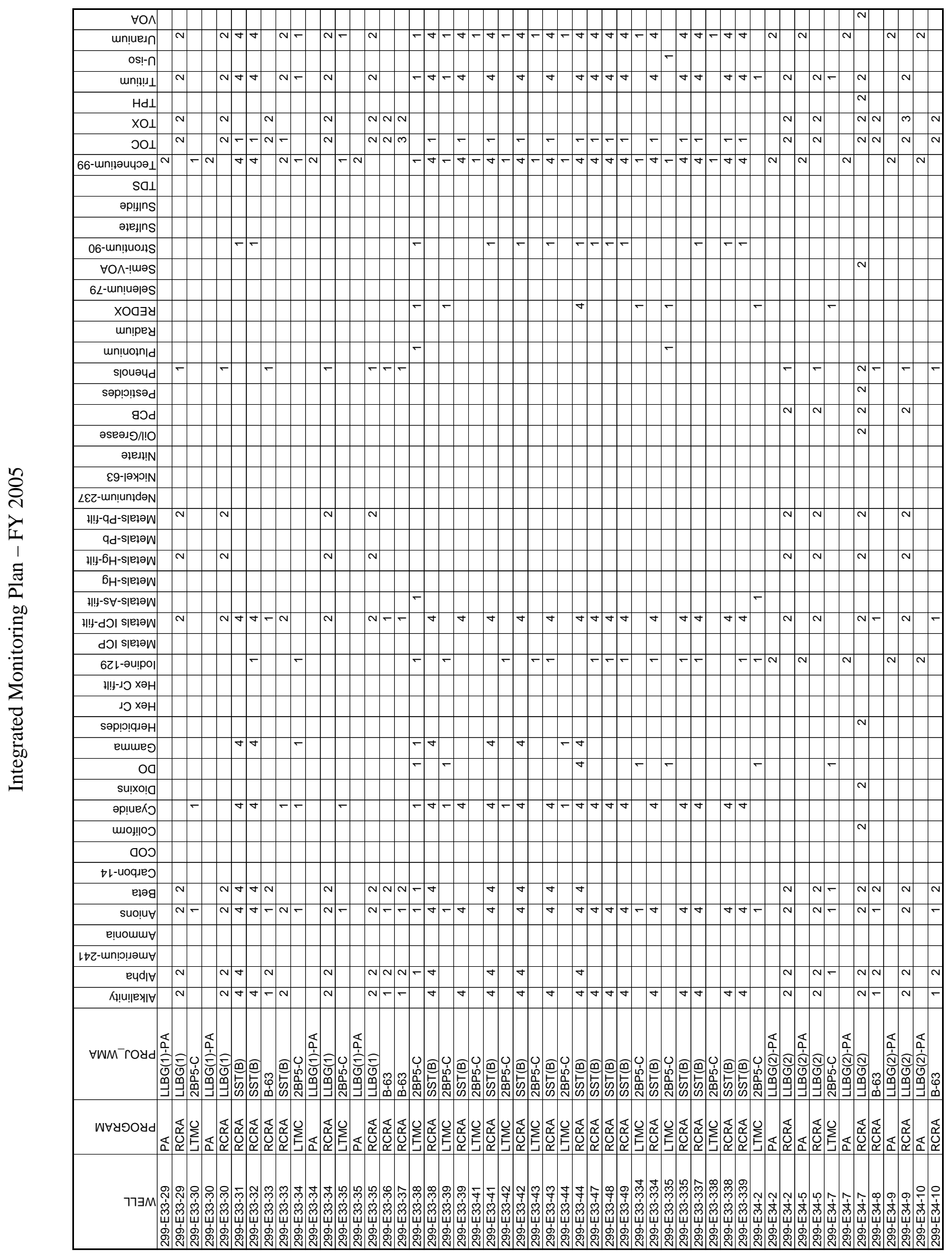




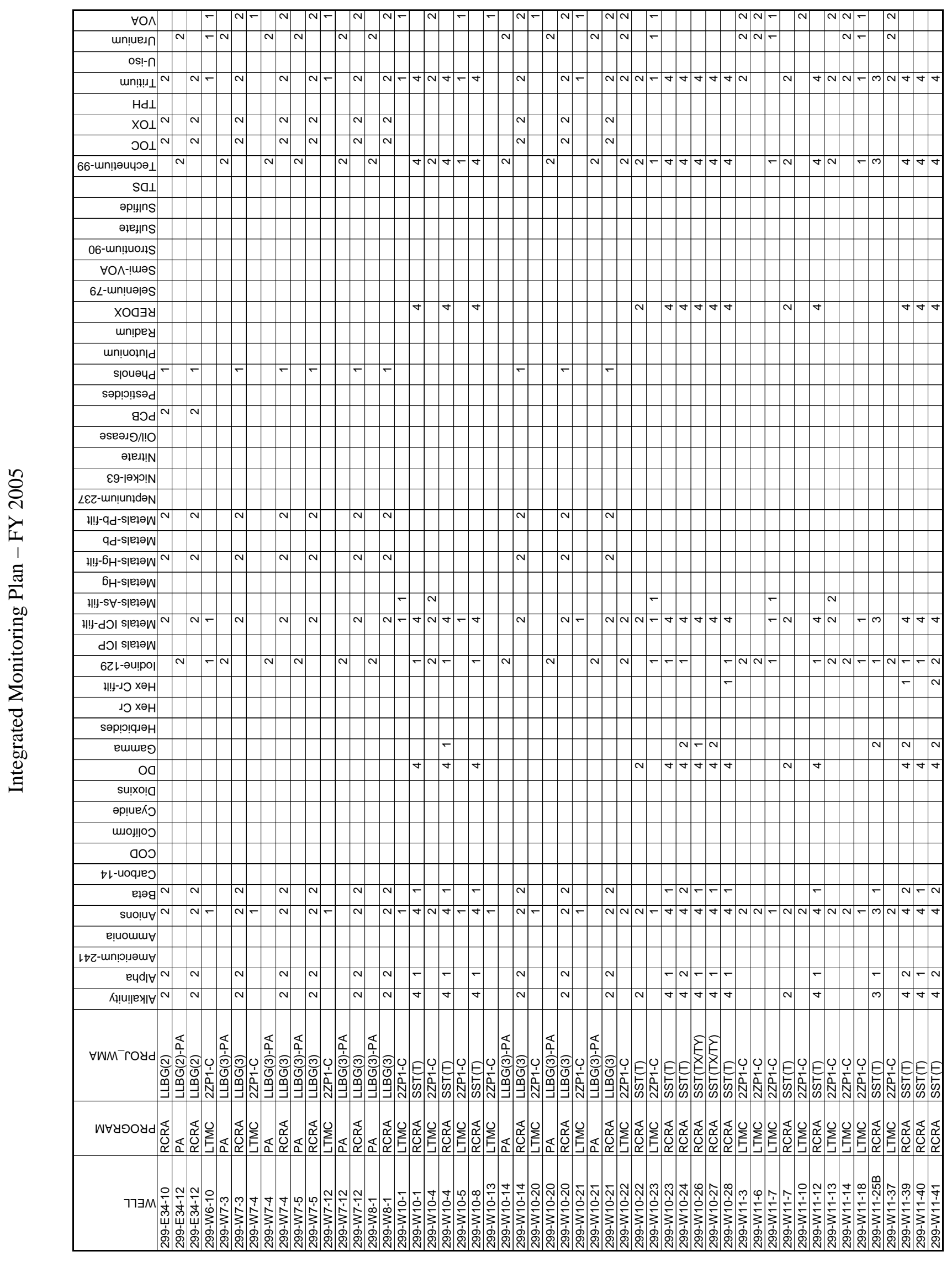




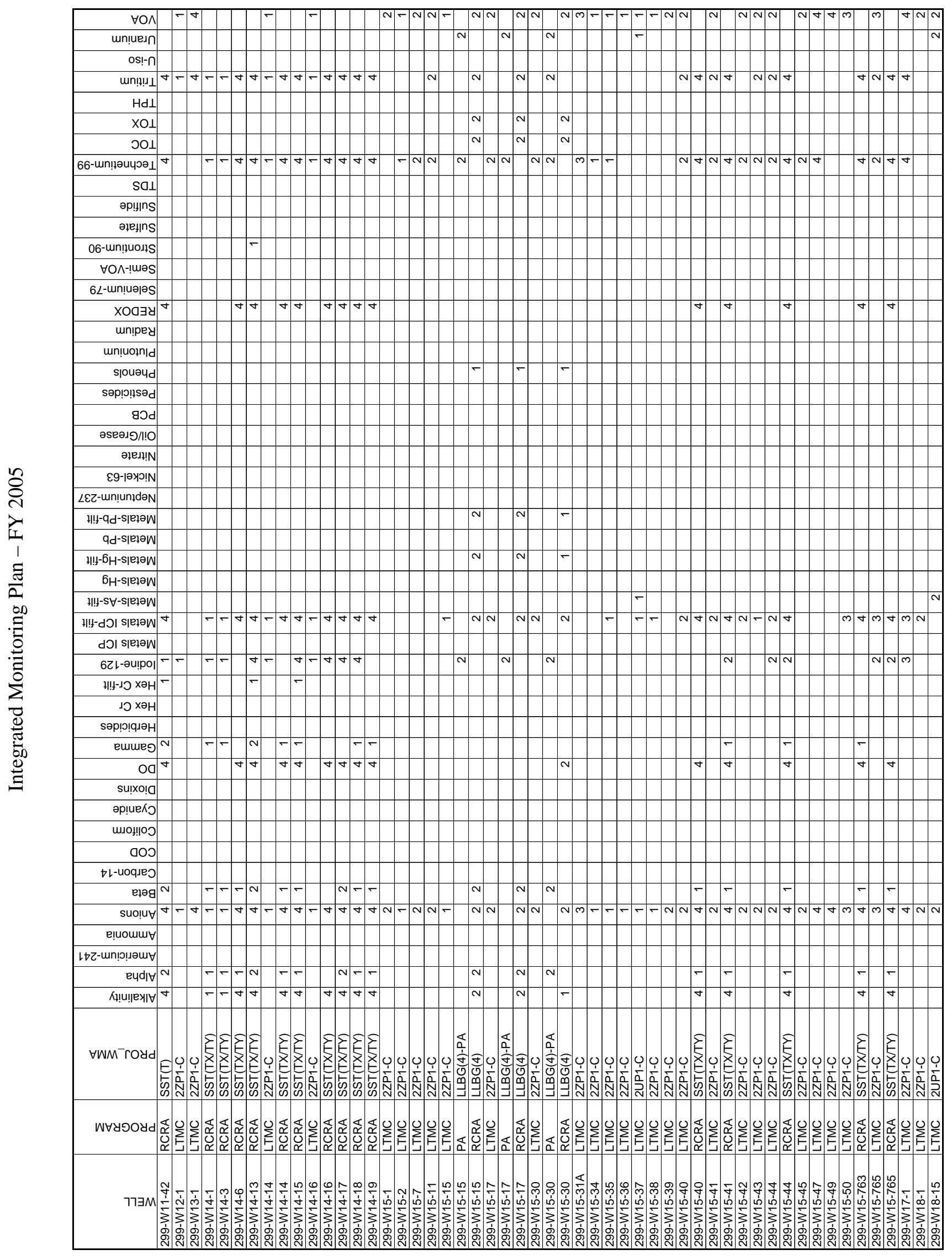




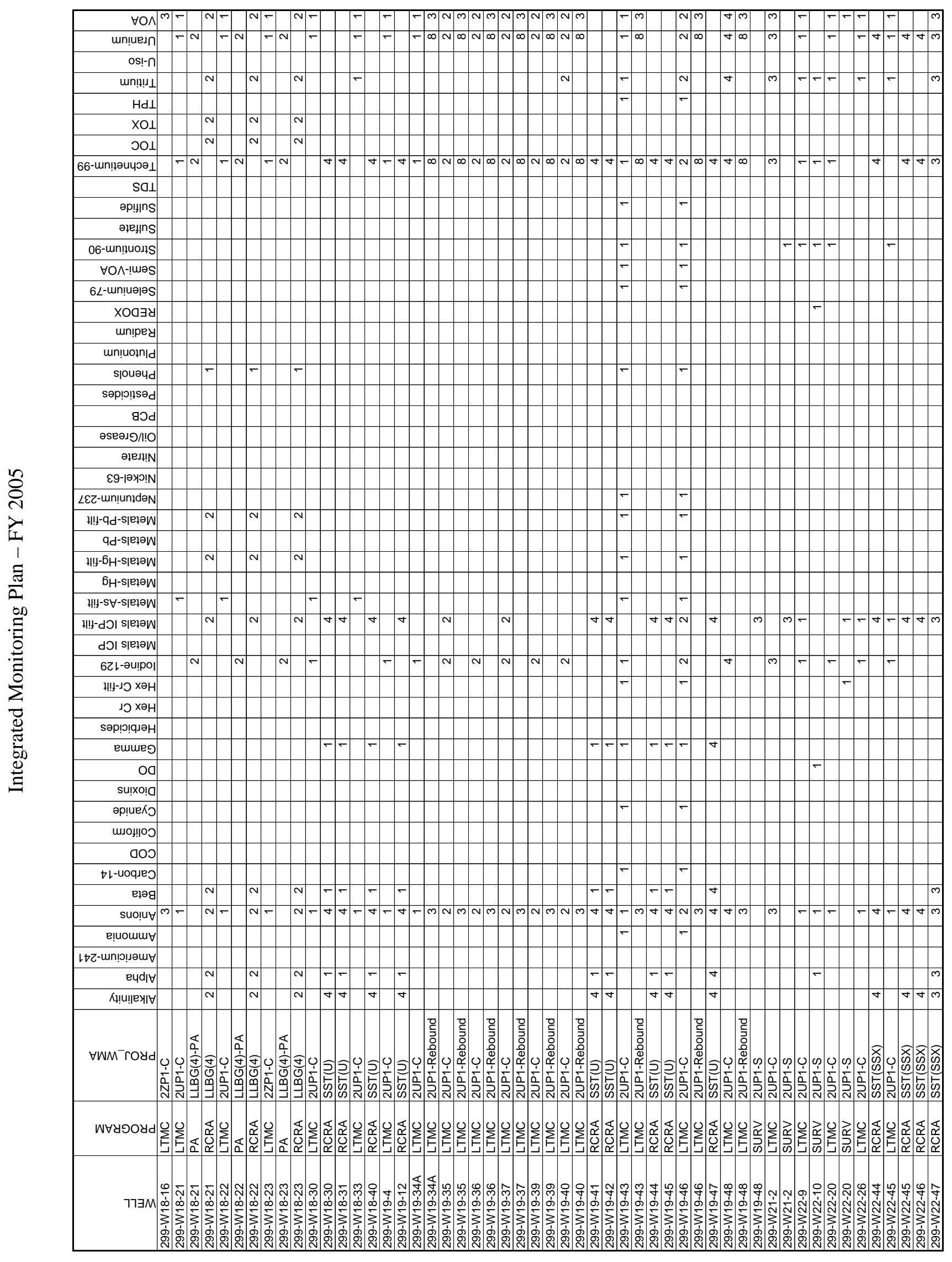




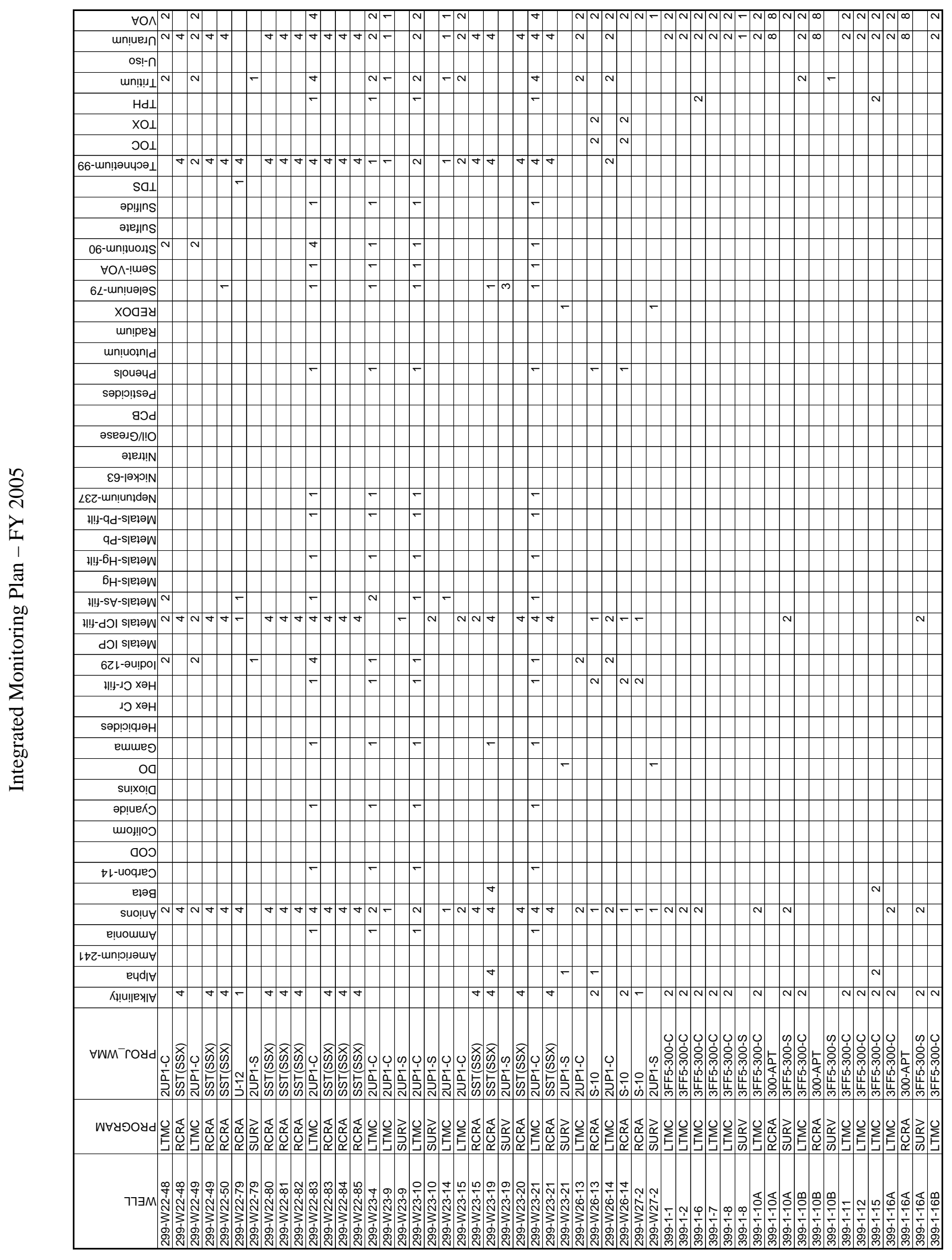




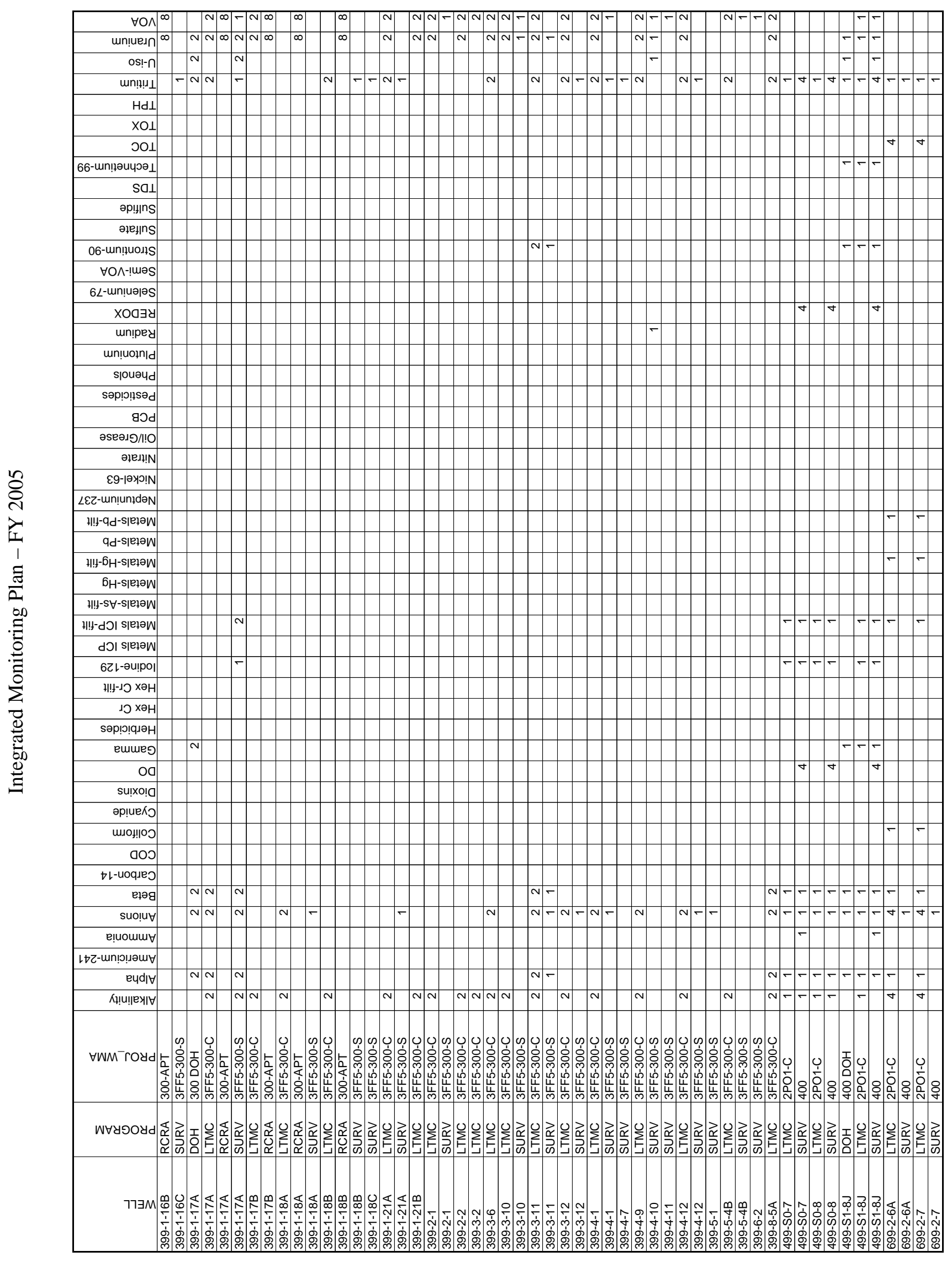




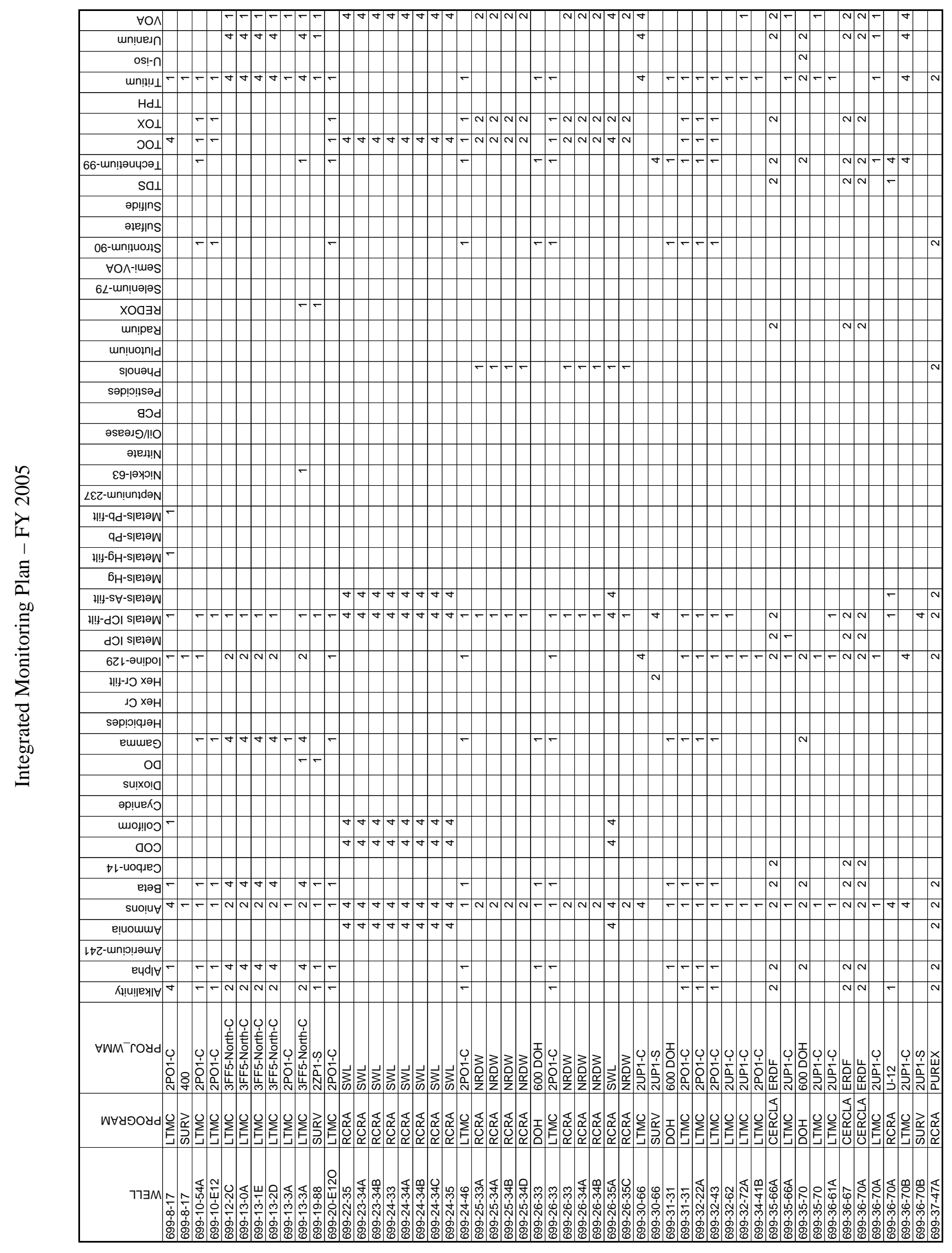




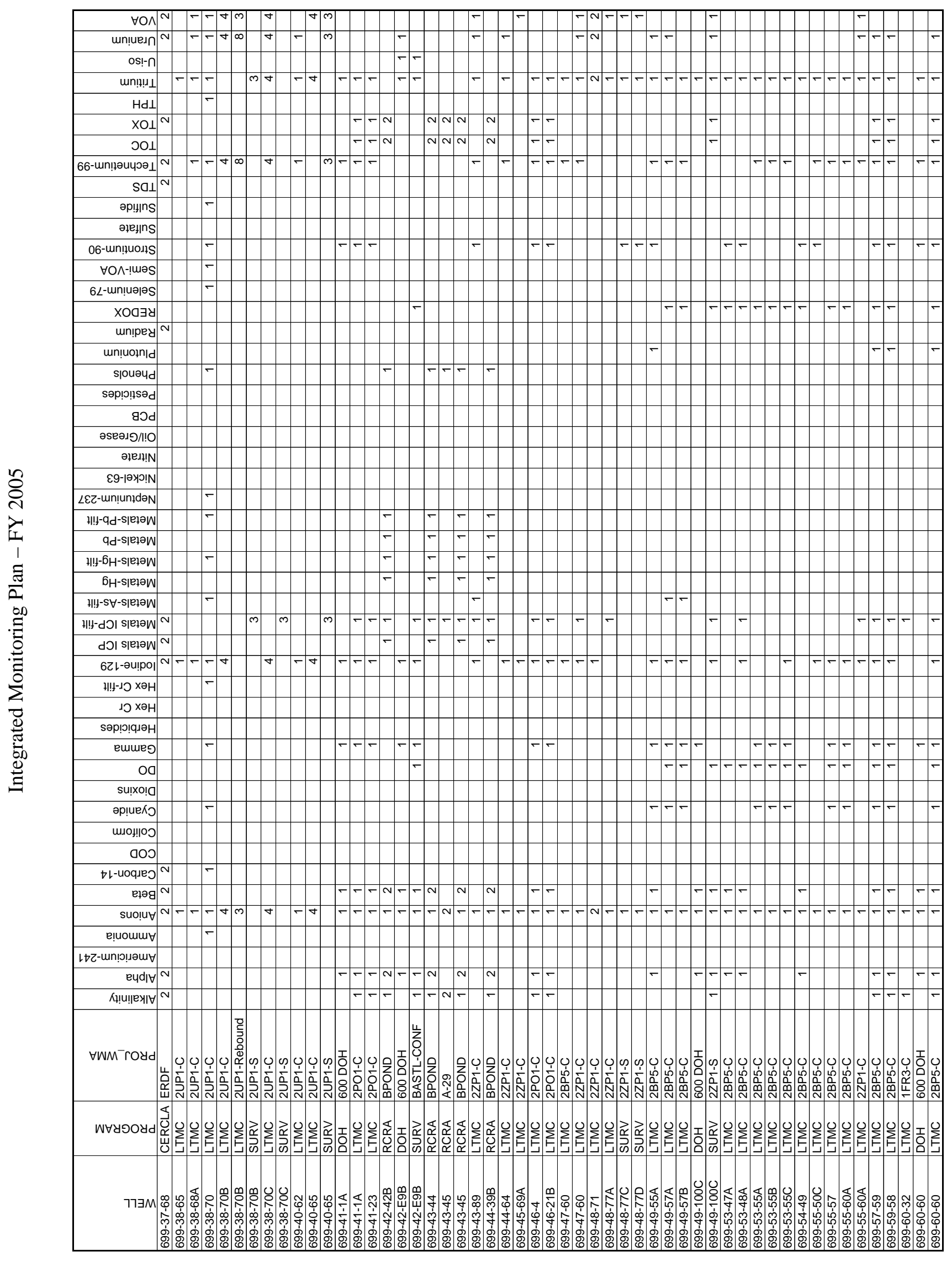




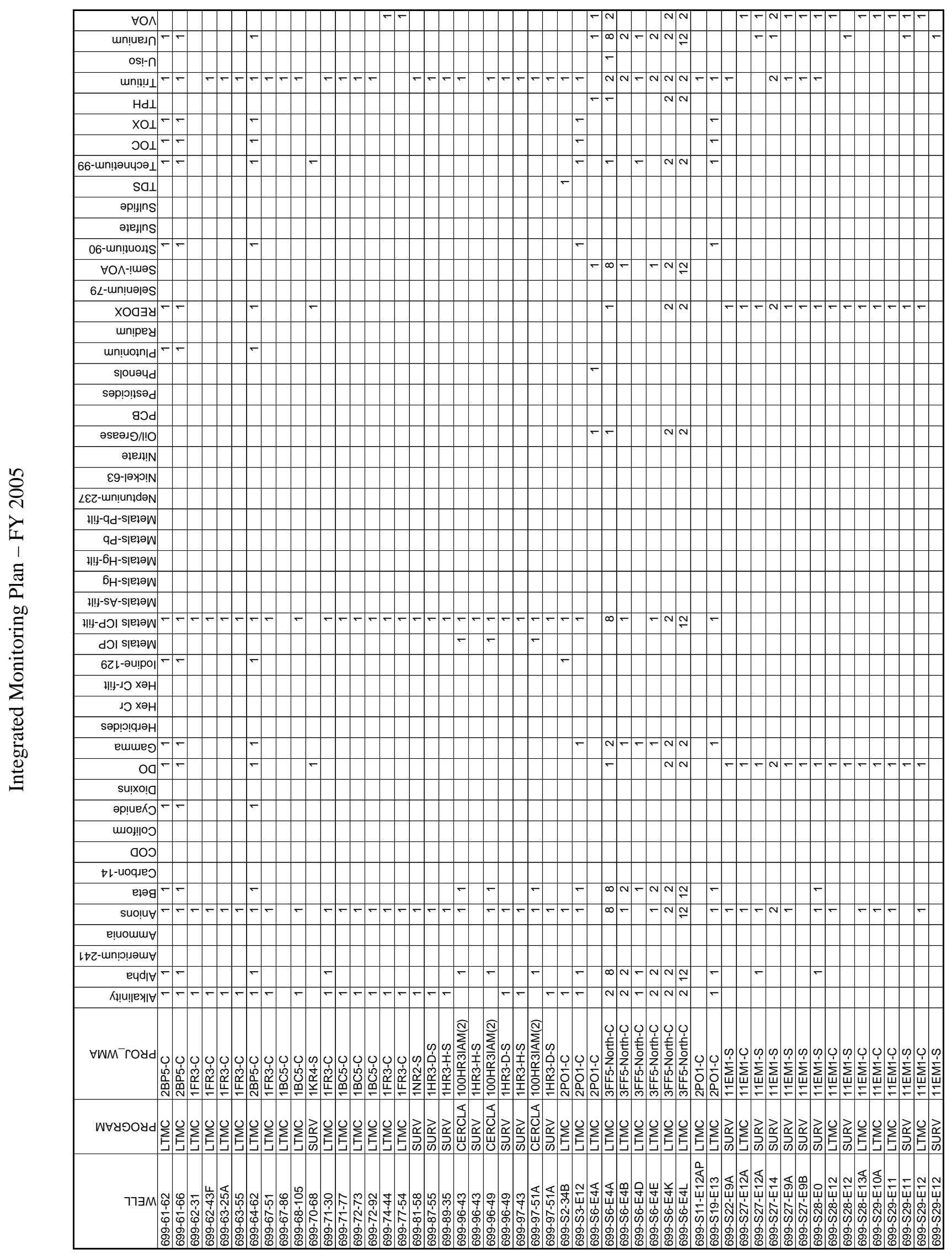




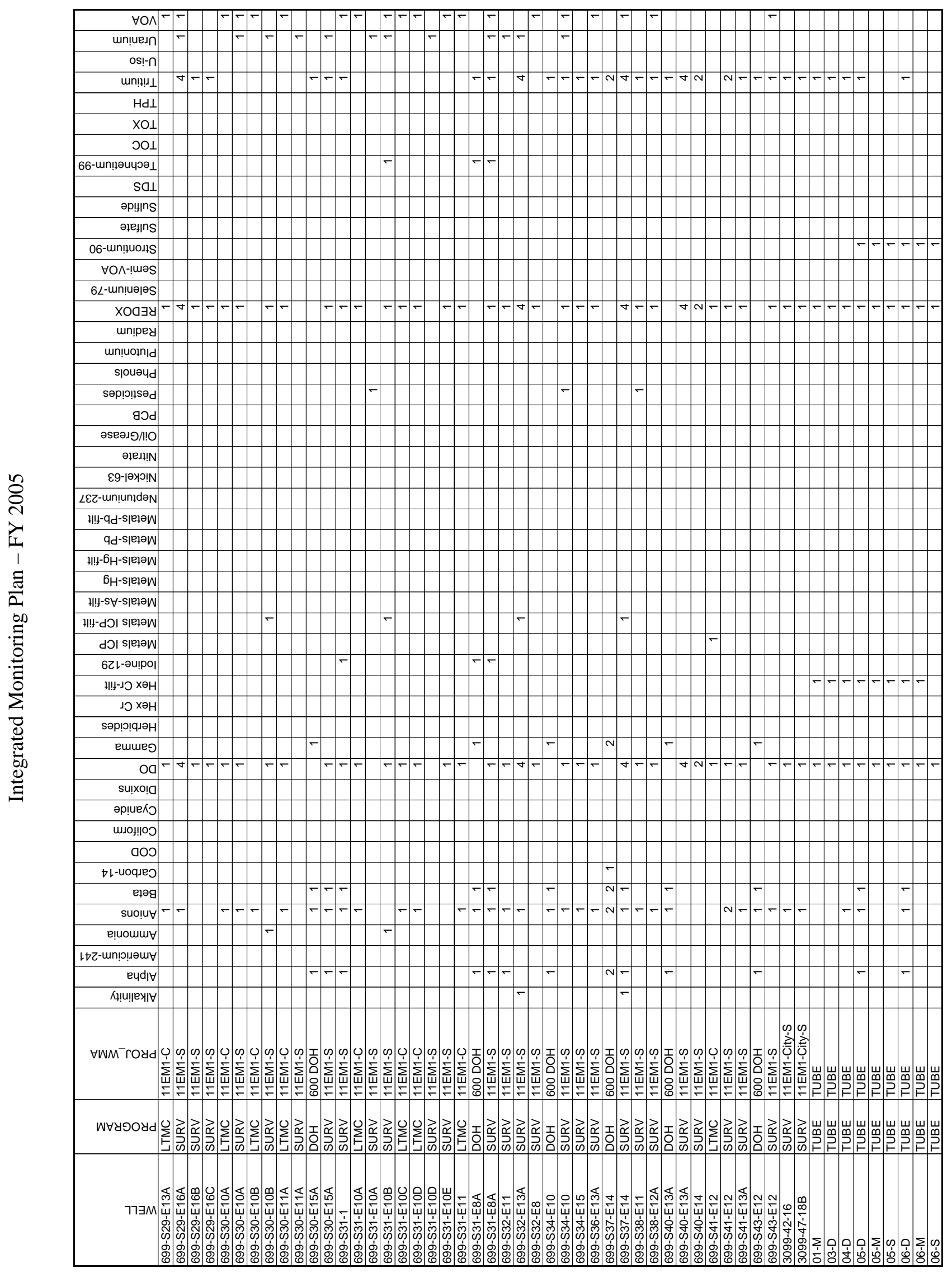




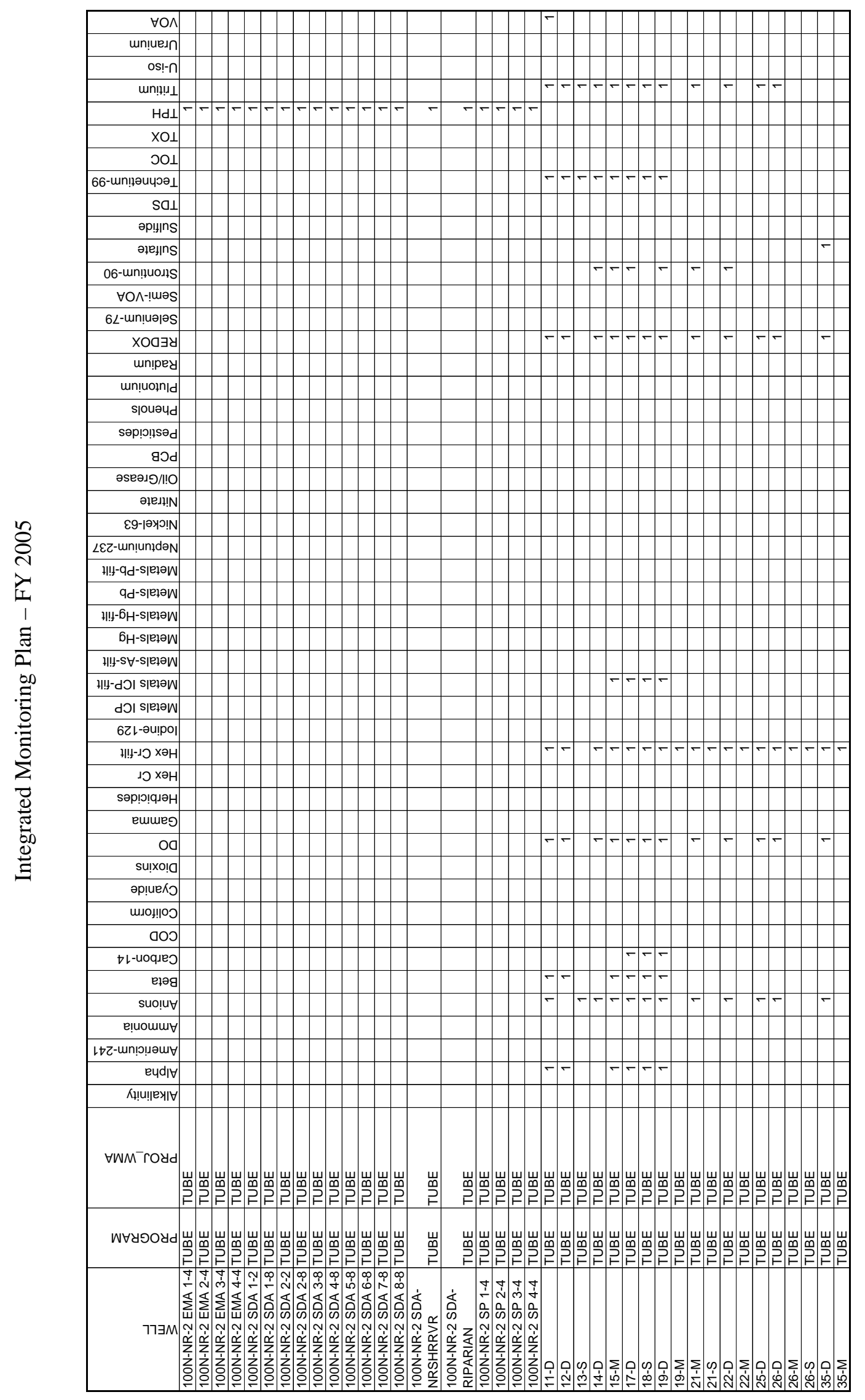




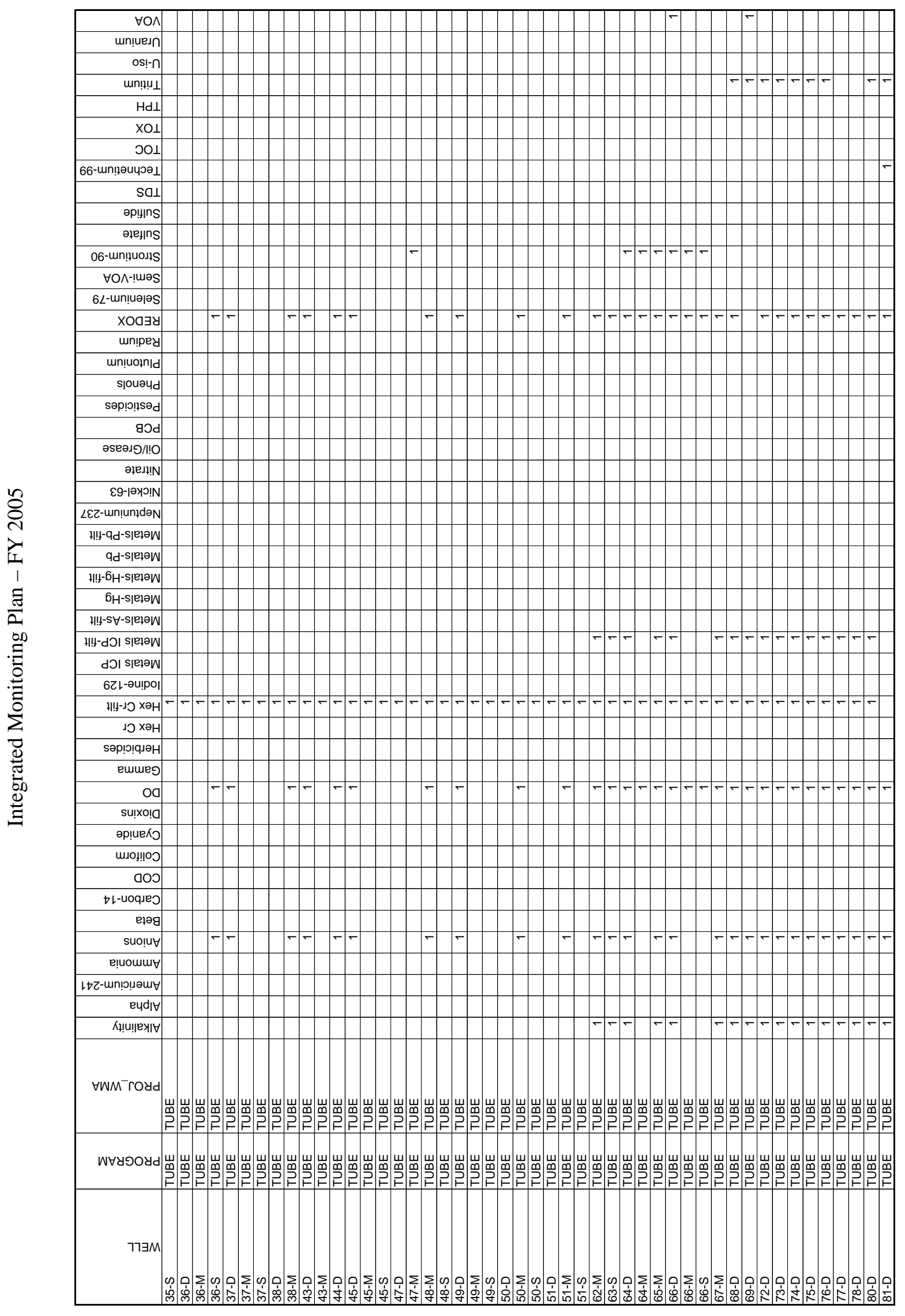




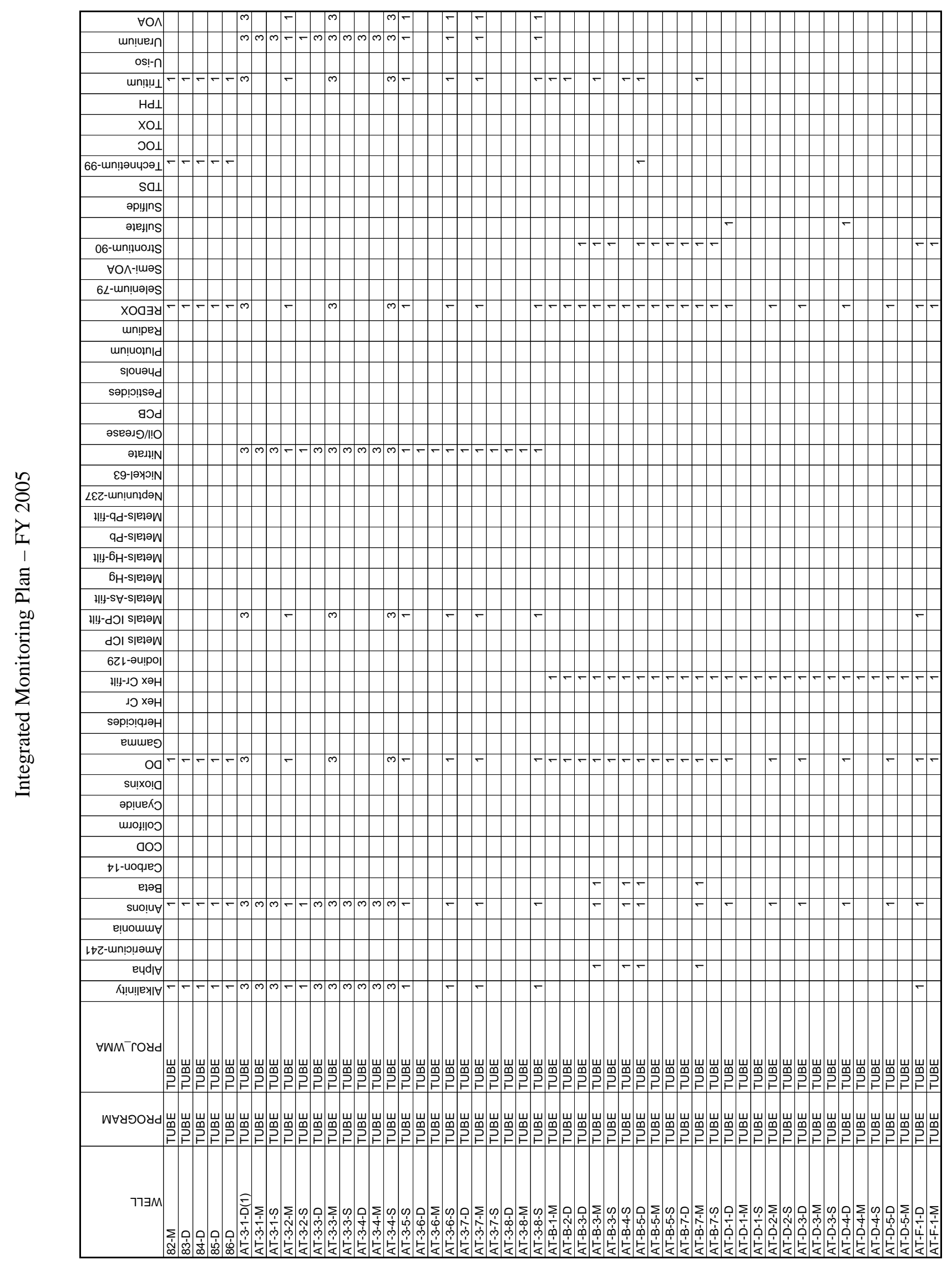




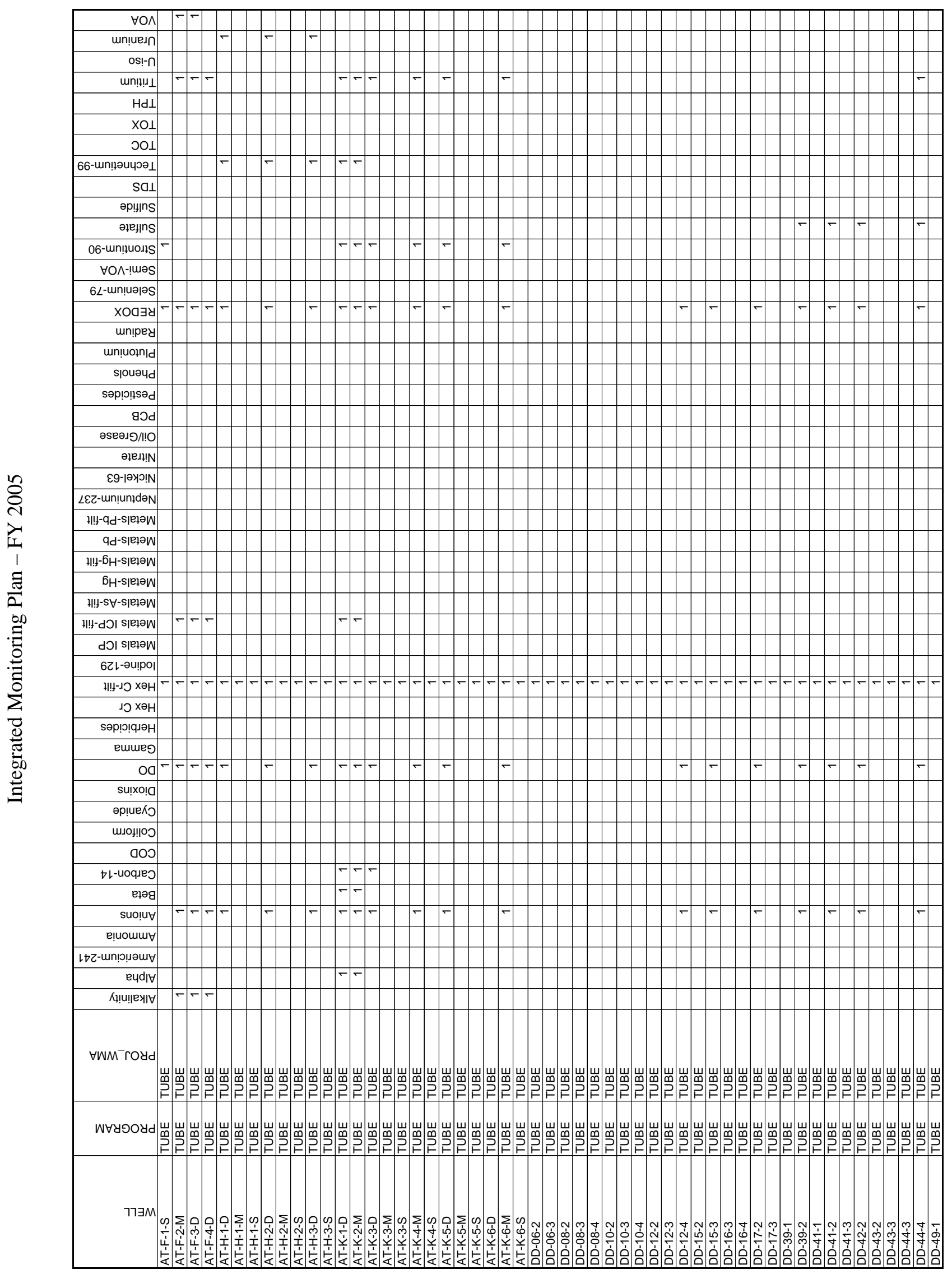




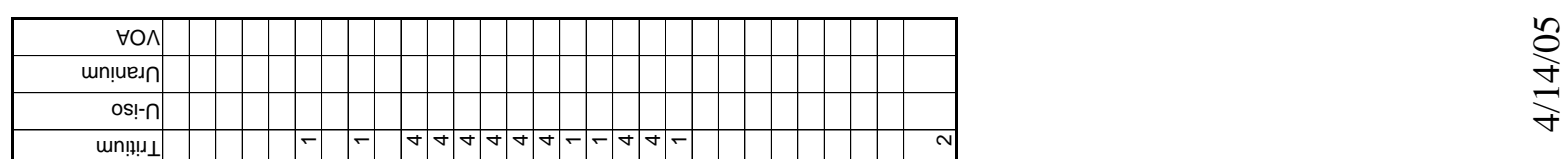

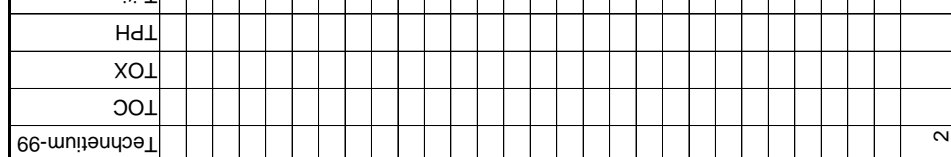

\begin{tabular}{|c|c|c|c|c|c|c|c|c|c|c|c|c|c|c|c|c|}
\hline sol & & & & & & & & & & & & & & & & \\
\hline әр!़ाns & & & & & & & & & & & & & & & & \\
\hline әңеңns & -1 & - & & & & & & & & & & & -1 & -1 & 7 & $\sqrt{-1}$ \\
\hline 06-un!̣uoxs & & & & & & 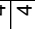 & & t & $|-1|$ & & +2 & & & & & \\
\hline 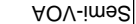 & & & & & & & & & & & & & & & & \\
\hline
\end{tabular}

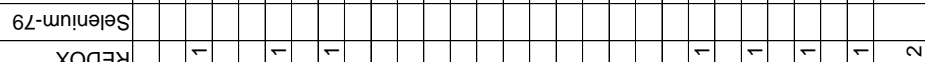

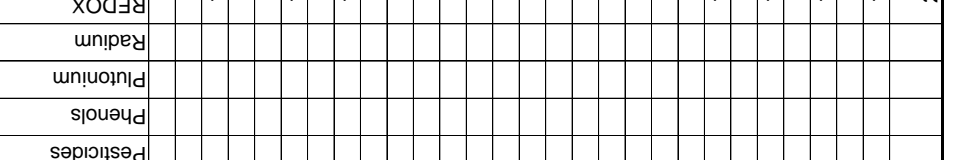

วรеәเป/IO

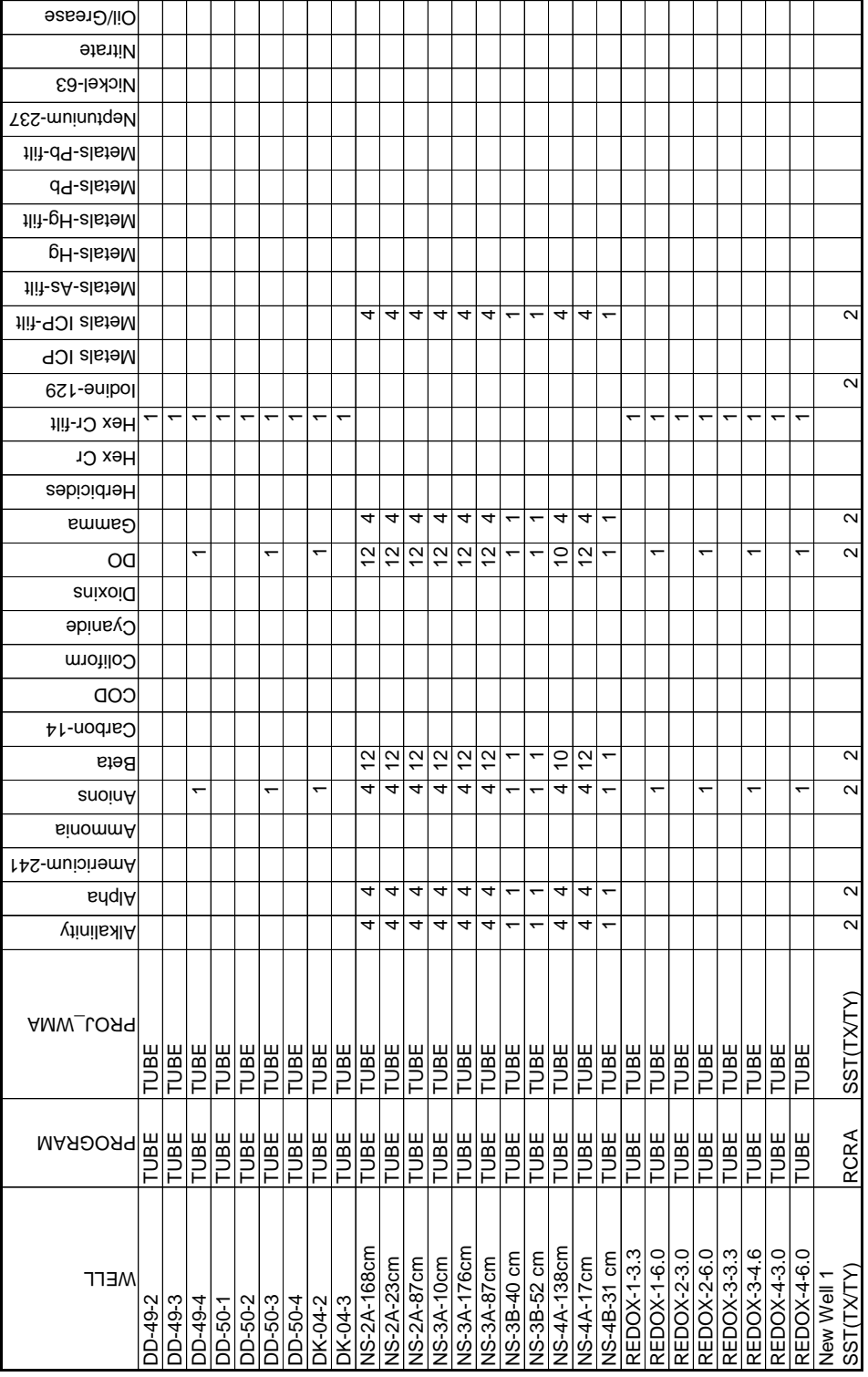




\section{Distribution}

No. of

Copies

ONSITE

9 DOE Richland Operations Office

B.L. Charboneau

R.D. Hildebrand

J.G. Morse

K.M. Thompson

A.C. Tortoso

DOE Administrative Record (2)

DOE Public Reading Room (2)

Bechtel Hanford, Inc.

S.G. Weiss
No. of

Copies

2 Fluor Hanford, Inc.

G.S. Thomas

E6-35

J.V. Borghese

E6-35

A6-33

A6-38

A6-38

A6-38

A6-38

H6-08

H2-53

H0-23

\section{Pacific Northwest National Laboratory}

P.E. Dresel

K6-96

J.S. Fruchter

K6-96

M.J. Hartman

K6-96

S.P. Luttrell (3)

K6-96

J.T. Rieger (5)

K6-96

D.L. Stewart

K6-96

D. Vela (project file)

K6-96

W.D. Webber

K6-96

This document is available on the Internet at http://groundwater.pnl.gov/. 